\title{
The Role of Nrf2 Activity in Cancer Development and Progression
}

\author{
Alina-Andreea Zimta ${ }^{1,+}{ }^{\text {, Diana Cenariu }}{ }^{1,+}$, Alexandru Irimie ${ }^{2,3}$, Lorand Magdo ${ }^{4}$, \\ Seyed Mohammad Nabavi ${ }^{5}$, Atanas G. Atanasov $6,7,8(\mathbb{D}$ and Ioana Berindan-Neagoe $1,4,9, * \mathbb{D}$ \\ 1 MEDFUTURE-Research Center for Advanced Medicine, Iuliu Hatieganu University of Medicine and \\ Pharmacy, Marinescu 23 Street, 400337 Cluj-Napoca, Romania; zimta.alina.andreea@gmail.com (A.-A.Z.); \\ diana.cenariu@umfcluj.ro (D.C.) \\ 2 Department of Surgical Oncology and Gynecological Oncology, Iuliu Hatieganu University of Medicine and \\ Pharmacy, 400015 Cluj-Napoca, Romania; airimie@umfcluj.ro \\ 3 Department of Surgery, The Oncology Institute "Prof. Dr. Ion Chiricuţa", 400015 Cluj-Napoca, Romania \\ 4 Research Center for Functional Genomics, Biomedicine and Translational Medicine, Iuliu Hatieganu \\ University of Medicine and Pharmacy, Marinescu 23 Street, 400337 Cluj-Napoca, Romania; \\ lorand.magdo@gmail.com \\ 5 Applied Biotechnology Research Center, Baqiyatallah University of Medical Sciences, 14359-16471 Tehran, \\ Iran; nabavi208@gmail.com \\ 6 Institute of Genetics and Animal Breeding of the Polish Academy of Sciences, 05-552 Jastrzebiec, Poland; \\ atanas.atanasov@univie.ac.at \\ 7 Department of Pharmacognosy, University of Vienna, Althanstrasse 14, A-1090 Vienna, Austria \\ 8 Institute of Neurobiology, Bulgarian Academy of Sciences, 23 Acad. G. Bonchev str., 1113 Sofia, Bulgaria \\ 9 Department of Functional Genomics and Experimental Pathology, The Oncology Institute "Prof. Dr. Ion \\ Chiricuta", Republicii 34-36 Street, 400015 Cluj-Napoca, Romania \\ * Correspondence: ioananeagoe29@gmail.com \\ + These authors have equal contribution.
}

Received: 11 October 2019; Accepted: 5 November 2019; Published: 8 November 2019

check for updates

\begin{abstract}
Nrf2 is a transcription factor that stimulates the expression of genes which have antioxidant response element-like sequences in their promoter. Nrf2 is a cellular protector, and this principle applies to both normal cells and malignant cells. While healthy cells are protected from DNA damage induced by reactive oxygen species, malignant cells are defended against chemo- or radiotherapy. Through our literature search, we found that Nrf2 activates several oncogenes unrelated to the antioxidant activity, such as Matrix metallopeptidase 9 (MMP-9), B-cell lymphoma 2 (BCL-2), B-cell lymphoma-extra large $(B C L-x L)$, Tumour Necrosis Factor $\alpha(T N F-\alpha)$, and Vascular endothelial growth factor A (VEGF-A). We also did a brief analysis of The Cancer Genome Atlas (TCGA) data of lung adenocarcinoma concerning the effects of radiation therapy and found that the therapy-induced Nrf2 activation is not universal. For instance, in the case of recurrent disease and radiotherapy, we observed that, for the majority of Nrf2-targeted genes, there is no change in expression level. This proves that the universal, axiomatic rationale that Nrf2 is activated as a response to chemo- and radiation therapy is wrong, and that each scenario should be carefully evaluated with the help of Nrf2-targeted genes. Moreover, there were nine genes involved in lipid peroxidation, which showed underexpression in the case of new radiation therapy: $A D H 1 A, A L D H 3 A 1$, $A L D H 3 A 2, A D H 1 B, G P X 2, A D H 1 C, A L D H 6 A 1, A K R 1 C 3$, and NQO1. This may relate to the fact that, while some studies reported the co-activation of $\mathrm{Nrf} 2$ and other oncogenic signaling pathways such as Phosphoinositide 3-kinases (PI3K), mitogen-activated protein kinase (MAPK), and Notch1, other reported the inverse correlation between Nrf2 and the tumor-promoter Transcription Factor (TF), Nuclear factor kappa-light-chain-enhancer of activated B cells (NF- $\kappa B$ ). Lastly, Nrf2 establishes its activity through interactions at multiple levels with various microRNAs. MiR-155, miR-144, miR-28, miR-365-1, miR-93, miR-153, miR-27a, miR-142, miR-29-b1, miR-340, and miR-34a, either
\end{abstract}


through direct repression of Nrf2 messenger RNA (mRNA) in a Kelch-like ECH-associated protein 1 (Keap1)-independent manner or by enhancing the Keap1 cellular level, inhibit the Nrf2 activity. Keap1-Nrf2 interaction leads to the repression of miR-181c, which is involved in the Nuclear factor kappa light chain enhancer of activated B cells (NF- $\mathrm{kB}$ ) signaling pathway. Nrf2's role in cancer prevention, diagnosis, prognosis, and therapy is still in its infancy, and the future strategic planning of Nrf2-based oncological approaches should also consider the complex interaction between Nrf2 and its various activators and inhibitors.

Keywords: Nrf2; Keap1; signaling pathway; oxidative stress; cancer; targeted genes

\section{Introduction}

The process of tumor formation and dissemination of malignant cells is strictly regulated by the external exposure of cells to harmful or protective elements. The interplay between these factors is seen at the cellular level through the strict modulation of signaling pathways [1-3] for which the activation or inhibition can either sustain or impair malignant transformation of normal cells and enhanced aggressiveness of cancer cells. Kelch-like ECH-associated protein 1(Keap1)-Nuclear factor erythroid 2-related factor 2 (Nrf2) is the most studied signaling pathway of cellular defense against oxidative stress [4-6]. The NFE2L2 gene encodes the Nrf2 protein [7], which is part of the "Cap ' $n$ ' Collar" (CNC) family of transcription factors (TFs) [8].

When reactive oxygen species (ROS) level rises, Nrf2 disassociates from its inhibitor, Keap1, and enters into the nucleus. Keap1 belongs to the Kelch family of proteins (KLHL), and it binds to the Nrf2-ECH homology (Neh2) domain of Nrf2 in a region containing 69-84 amino acids flanked by the ETGE motif [9]. The ubiquitination of lysine in the Neh2 domain and consequent proteasomal degradation is mediated by Keap1, which represents the link between Nrf2 and the ubiquitination ligase Cullin-3 (Cul-3) [10]. Translational, post-translational, transcriptional, and epigenetic mechanisms also regulate Nrf2 distribution, as well as other protein partners. P62 is an adaptor protein which delivers ubiquitinated proteins to the autophagosome. This protein interacts with Keap1, thus increasing the intranuclear concentration of Nrf2 [11]. At the same time, p62 is a target gene for the Nrf2 transcription factor [12]. P21 is a positive regulator of Nrf2, via direct interaction, which stabilizes the Nrf2 protein [13]. The globular adiponectin (gAcrp) induces the production of the pro-inflammation Tumour Necrosis Factor $\alpha$ (TNF- $\alpha$ ) and Interleukin 1 beta (IL-1 $\beta$ ) in adipocyte-associated macrophage, but also raises the level of p62, a negative regulator of pro-inflammatory cytokines [14]. P62 binds to Keap1 and mediates its degradation [11,15].

Inside the nucleus, NRF2 forms a heterodimer with small V-Maf Avian Musculoaponeurotic Fibrosarcoma Oncogene MAF proteins (sMAF) and regulates the expression of genes that contain the antioxidant response elements (AREs) or the MAF recognition elements (MARE) in their promoter region [16,17]. Nrf2 controls an estimated number of 250 genes, across different species involved mainly in endogenous antioxidant protection and detoxification of reactive oxygen species (ROS) $[18,19]$.The following genes are some of its most important targets: $\mathrm{NAD}(\mathrm{P}) \mathrm{H}$ dehydrogenase (quinone) 1 (NQO1), Glutathione S-transferase 1 (GST) [20], heme oxygenase-1 (HMOX1), glutamate-cysteine ligase (GCL), peroxiredoxins, and Glutathione (GSH) synthesis enzyme [21]. Mutation of Nrf2 or mutations of its negative regulator Keap1 can disrupt their interactions, which may account for overactivation of Nrf2 signaling [22].

Several authors already showed the defensive role of Nrf2 in various malignancies, neurodegenerative diseases, cardiovascular disorders, aging, inflammation, or photo-oxidative stress [23]. Moreover, multiplication and overgrowth of tumoral cells were shown to take place due to hyperactivation of Nrf2, which prevents cancer cells from undergoing apoptosis and cellular death, thereby rendering it resistant to chemotherapy or radiotherapy [24].

There are several types of cancers in which this mechanism was demonstrated, and tumors were proven to use Nrf2 as a self-protective mechanism [25]. 
In this review, we analyze the involvement of Nrf2 in cancer installment and progression focusing on the interactions this signaling pathway establishes with various kinds of regulators: proteins, microRNAs, and interactions with other signaling pathways and transcription factors. We also take a look at the The Cancer Genome Atlas (TCGA) data regarding the activity of Nrf2 in lung cancer and how it affects the cellular response to radiation therapy.

\section{The Nrf2 Involvement in Cancer Development and Progression}

Nrf2 is a cytoprotective transcription factor which has both a positive effect and a negative effect on cancer [26,27]. Nrf2 protects both normal and cancerous cells from oxidative damage, meaning that it inhibits malignant transformation; however, once cancer is installed, it offers resistance to therapy [28] (Figure 1). Anti-cancer therapy acts as a selective force over the tumor cell population, and it stimulates the development of resistance. In the case of resistance to chemotherapy, these are fixing the drug-induced cell damage, creating a drug-suppressing environment, and avoiding intracellular drug exposure [29]. Nrf2 plays crucial roles in chemotherapy resistance by stimulating drug metabolism or drug efflux [24].

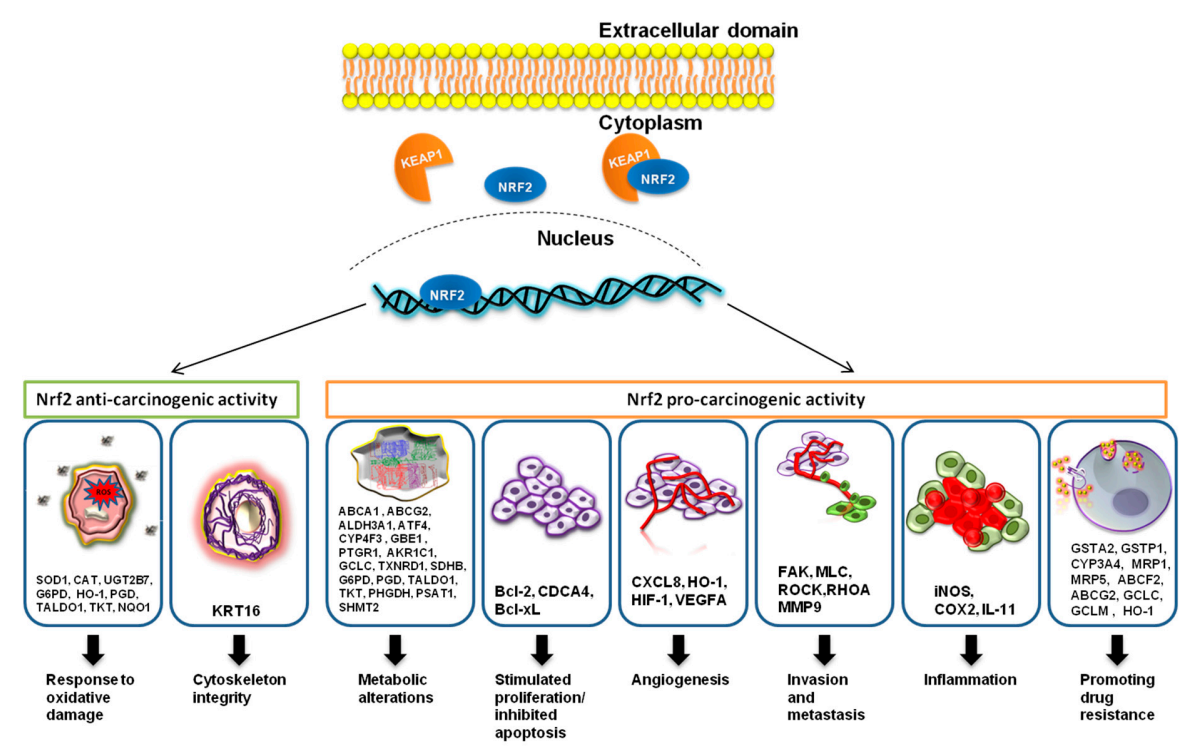

Figure 1. Nrf2, through its targeted genes, has an anti-carcinogenic role in the case of normal cells and a pro-carcinogenic effect in the case of transformed malignant cells. Nrf2 stimulates the expression of SOD1, CAT, UGT2B7, G6PD, HO-1, PGD, TALDO1, TKT, and NQO1 genes, and it is involved in the protection of normal cells against intrinsic or extrinsic oxidative stress. Nrf2 also induces the expression of the KRT16 gene, which helps in the maintenance of cytoskeleton integrity. In pre-cancerous lesions or cancerous cells, Nrf2 causes metabolic alterations such as anaerobic glycolysis, altered pentose phosphate pathway, and fatty-acid biosynthesis, among others, which induce the shift to anabolism with the help of the following targeted genes: ABCA1, ABCG2, ALDH3A1, CYP4F3, GBE1, PTGR1, AKR1C1, GCLC, TXNRD1, SDHB, G6PD, PGD, TALDO1, and TKT. Nrf2 activation also leads to the stimulated proliferation and inhibition of apoptosis, by enhancing the expression of the anti-apoptotic genes $B C L-2$ and $B C L-X L$ and the proliferation gene CDCA4. With the help of C-X-C Motif Chemokine Ligand 8 (CXCL8), Heme oxygenase 1 (HO-1), and Hypoxia-inducible factor 1 (HIF-1), Nrf2 was proven to induce angiogenesis in cancer. The overstimulation of Vascular endothelial growth factor A (VEGFA) could also be involved in cancer. Nrf2 can either stimulate or inhibit invasion and metastasis. The targeted genes involved in the stimulation are FAK, MLC, ROCK, RHOA, and MMP9. Nrf2, however, also downregulates the invasion-promoting gene, Snail. Nrf2 inhibits Nrf2-induced inflammation with the help of its targeted genes $i N O S, C O X 2$, and $I L-11$, while it also inhibits the expression of pro-inflammatory cytokines (not illustrated) $T N F \alpha, I L-6, I L-8$, and $I L-1 \beta$. The most important cancer-promoting action of Nrf2 is the promotion of chemoresistance through multiple mechanisms due to its targeted genes GSTA2, GSTP1, CYP3A4, MRP1, ABCF2, ABCG2, GCLC, GCLM, MRP5, and HO-1. 
The different roles of Nrf2 in cancer progression were analyzed in a study from 2016, with Keap1 knockdown mice. The mice grew smaller urethane-induced tumors and had the following antioxidant genes upregulated: Catalase (Cat), Glutathione peroxidase 2 (Gpx2), Glutathione-S-transferase a4 (Gsta4), Ppargc1A and Glutathione reductase (Gsr). However, when these tumors were transplanted into nude mice, the tumors were more aggressive [30].

The reasons behind the overactivation of Nrf2 in cancer are DNA mutations, epigenetic changes, and modifications in the protein structure. In some cancer types, one or both Keap1 and Nrf2 are mutated, which does not allow a proper chemical interaction between the two [22,31-33]. For instance, Nrf2 is mutated in the Keap1-binding region in preneoplastic lesions in the liver [34].

In many cancers, the general methylation pattern of the DNA is changed, and the promoter region of Keap1 becomes hypermethylated, resulting in the decreased transcription of the Keap1 protein and the release of Nrf2 [31,35-37]. Another mechanism is the accumulation of fumarate and the succination of cysteine in Keap1 protein, which abolishes its sensitivity to oxidative stress [38,39], or the increased level of p21 [40] and p62 [41] proteins, which inhibit the interaction between Keap1 and Nrf2 [31,42].

In classical Hodgkin lymphomas, it was found that the increased expression of Nrf2 is associated with a limited form of the disease as opposed to the advanced forms [43]. In glioblastoma cells, Nrf2 overexpression leads to increased proliferation and oncogenic transformation [44].

Nrf2 is involved in maintaining cancer cell proliferation and invasion. In hepatocellular carcinoma, it was proven that the upregulation of the Nrf2 signaling pathway was correlated with the increased level of MMP9 (matrix metallopeptidase 9) and Bcl-xL (B-cell lymphoma extra large). MMP-9 is a metalloproteinase involved in cancer invasion through degradation of the basal membrane, and Bcl-xL is an anti-apoptotic factor [45]. In glioma cells, Nrf2 increased the expression level of MMP9 [46]. The Nrf2 signaling pathway contributed to decreased apoptosis through the overstimulation of the anti-apoptotic protein, $B c l-2$. There is an ARE region in the -3148 and -3140 reverse strands of the promoter region of $B c l-2$ [47].

In cervical cancer, the Nrf2 signaling pathway leads to increased proliferation and inhibits apoptosis [48]. In breast cancer, Nrf2 activation leads to the overexpression of Rho and the downstream proteins FAK (focal adhesion kinase 1), MLC (modulator of volume-regulated anion channel current 1), and ROCK (Rho-associated coiled-coil-containing protein kinase 1), while inhibiting the expression of estrogen-related receptor $\alpha$ (ERR1). Nrf2 also directly interacts with Breast cancer type 1 susceptibility protein (BRCA1), leading to increased stability of the BRCA protein. In the absence of $B R C A$ expression, estrogen restores Nrf2 activation, causing decreased production of ROS in vitro and the protection of mammary gland cells [49]. The exogenous antioxidant, phospholipid hydroperoxide glutathione peroxidase (PHGPX), or pro-oxidant, 15-lipoxygenase (15-LOX), inhibited the expression of the vascular cell adhesion molecule (VCAM) via Nrf2 interaction in the promoter region of this gene [50].

There is a negative regulation between E-cadherin and the Nrf2 protein. E-cadherin impairs the nuclear localization of Nrf2, with the help of $\beta$-catenin. In hepatocellular carcinoma, however, E-cadherin is inhibited due to the action of Transforming Growth Factor Beta 1 (TGF $\beta$ ) [51]. However, in lung fibrosis, it was reported that the Nrf2 protein inhibits epithelial-to-mesenchymal transition (EMT) by repressing the expression of Snail genes [52].

In bladder cancer tissue, the overexpression of HO-1 was correlated with the increased expression of Nrf2, HIF- $1 \alpha$, HIF- $2 \alpha$, and VEGFA. In sera of bladder cancer patients, the pro-inflammatory cytokines IL-6 and IL-8 were also elevated, along with the pro-angiogenic factor VEGFA [53].

The TNF- $\alpha$ cytokine functions both as a promoter and as an inhibitor of the Nrf2 pathway. At average concentrations ( $2-5 \mathrm{ng} / \mathrm{mL}$ ), TNF- $\alpha$ mediated the nuclear import of Nrf2 and the transcription initiation of its target genes, while, at high concentrations ( $>10-50 \mathrm{ng} / \mathrm{mL}$ ), it inhibited the Nrf2 pathway [54].

Hypoxic conditions are also regulators of the Nrf2 stimulation of transcription. In acute hypoxia, this TF binds less commonly in the enhancer or promoter region of HMOX1, than in the case of acute hypoxia [55]. 
The exposure of HepG2 cells to homocysteine results in the stabilization of Nrf2, and the transcription activation of glutamate cysteine ligase (GCLc). The stimulated expression of GCLc leads to the synthesis of glutathione, an important antioxidant, thus protecting the cancerous cells from the damage caused by high oxidative stress [56].

In mucoepidermoid carcinoma of the lung, HMOX1 overexpression was also associated with the inhibition of cell-cycle progression proteins Cyclin D1 (CCND1) and CCND2, and the stimulated transcription of the cell-cycle arrest proteins Gastrin (GAS) and Cyclin-dependent kinase inhibitor 1C (CDKN1C). The small interfering RNA (siRNA)-mediated silencing of HO-1 decreased the expression level of invasion promoters ( $M M P-9, M M P-1$, and $M M P-12)$, pro-inflammatory cytokines (IL-6, IL-1 $\beta$, and TNF $\alpha$ ), and the pro-angiogenic factor VEGFA [57]. An important finding is the fact that Nrf2 is overexpressed in lung cancer and breast cancer tissue, concomitant with the anti-inflammatory interleukin IL-11. This interleukin belongs to the IL-6 family, and it is associated with the inflammasome-induced epithelial cancers such as gastric and breast cancer [58]. Nrf2 antioxidant activity is involved in regulatory $\mathrm{T}$ cells ( $\mathrm{T}$ regs) apoptosis, which counteracts the beneficial role of Programmed cell death 1 ligand 1 (PD-L1) antitumor therapy [59].

In laryngeal carcinoma tissue versus healthy adjacent tissue, it was found that Nrf2 is overexpressed and localized mainly in the nucleus, while Keap1, NQO1, and HO-1 were found mainly in the cytoplasm. There is a positive correlation between Nrf2, Keap1, NQO1, and HO-1 [60]. In the human hepatocarcinoma cell line, carbon monoxide (CO) enhanced the activity of Nrf2 and the NQO1 gene [61].

An illustration of cancer-related genes modulated by Nrf2 is shown in Figure 1.

In cancer cells, it was proven that Nrf2 stimulates the multidrug-resistance-associated protein-1 (MRP1). Moreover, the MRP1 gene has two ARE-binding regions (ARE1/2) in its promoter, which can explain the synchronous expression of Nrf2 and MRP1 [62]. Nrf2 also stimulates the expression of other genes which promote chemoresistance: ATP Binding Cassette Subfamily G Member 2 (ABCG2) [63], Glutathione S-Transferase Alpha 2 (GSTA2), Glutathione S-Transferase Pi 1 (GSTP1), Cytochrome P450 Family 3 Subfamily A Member 4 (CYP3A4), Heme Oxygenase 1 (HO-1), MRP5 [64], ATP Binding Cassette Subfamily F Member 2 (ABCF2) [65], Glutamate-Cysteine Ligase Catalytic Subunit (GCLC), and Glutamate-Cysteine Ligase Modifier Subunit (GCLM) [66]. In colon cancer, Nrf2 is overexpressed, and, by elevating the expression of as P-glycoprotein (Pgp) and breast cancer resistance protein (BCRP), Nrf2 induces doxorubicin resistance by drug efflux [67]. Nrf2 is also involved in cell metabolism, which is one of the primary mechanisms for chemoresistance. It was proven that the overexpression of Nrf2 leads to changes in the cell metabolism; for instance, it changes anabolism [68], or it inhibits lipogenesis and simulates the $\beta$-oxidation of fatty acids [69]. Nrf2 regulates the genes involved in phosphate pentose pathways, such as Glucose-6-Phosphate Dehydrogenase (G6PD), Phosphogluconate Dehydrogenase (PGD), Transaldolase 1 (TALDO1), and Transketolase (TKT), and the synthesis of purines. Its activity involves the inhibition of Keap1 and the activation of the signaling pathway hosphatidylinositol-4,5-bisphosphate 3-kinase (PI3K)/RAC-alpha serine/threonine-protein kinase (Akt). Moreover, for metabolism reprogramming, Nrf2 also interacts and modulates the activity of other TFs such as p53, c-Myc, and HIF1 $\alpha$ [70]. Nrf2 regulates genes involved in serine and glycine metabolism, such as Phosphoglycerate Dehydrogenase (PHGDH), Phosphoserine Aminotransferase 1(PSAT1), and Serine Hydroxymethyltransferase 2 (SHMT2) [71], or the glycolysis and the tricarboxylic acid cycle, by stimulating the expression of Abhydrolase Domain Containing 14B (ABHD14B), Acyl-CoA Thioesterase 13 (ACOT13), Aldo-Keto Reductase Family 1 Member C1 (AKR1C1), Aldehyde Dehydrogenase 3 Family Member B1 (ALDH3B1), Glutamate-Cysteine Ligase Catalytic Subunit(GCLC), Kynureninase (KYNU), LDL Receptor Related Protein 8 (LRP8), Nicotinamide Phosphoribosyltransferase (NAMPT), Prostaglandin E Synthase (PTGES), Prostaglandin Reductase 1 (PTGR1), Solute Carrier Family 27 Member 5 (SLC27A5), and Thioredoxin Reductase 1 (TXNRD1) [72]. Nrf2 targets the Transketolase (TKT) gene, which encodes for an enzyme involved in the pentose phosphate pathway (PPP) and protects cancerous cells from treatment-induced oxidative stress [73]. 
The Nrf2 signaling pathway is, in turn, repressed by multiple nuclear receptors. Retinoid $X$ receptor alpha $(\mathrm{RXR} \alpha)$ and Peroxisome proliferator-activated receptor gamma (PPAR $\gamma$ ) bind to the retinoic acid response element in DNA or the peroxisome proliferation-activated receptors. Estrogen receptor alpha $(\mathrm{ER} \alpha)$, Estrogen-related receptor $\beta(\mathrm{ERR} \beta)$, and Glucocorticoid receptor (GR) bind in the promoter region of their targeted genes [74].

Nrf2 stability is increased through the binding of Inhibitor of apoptosis-stimulating protein of p53 (iASPP), a negative regulator of the p53 signaling pathway, which cooperates with Keap1 for Nrf2 binding [75]. Nrf2-mediated cell survival after oxidative stress is induced by the Eukaryotic Translation Initiation Factor 2 Alpha Kinase 3 (EIF2AK3, also known as PERK) protein [76].

The wild-type p53 interacts with the promoter of Nrf2, and it induces its suppression; however, in the case of cancer, the mutated p53 can no longer bind to the promoter region of Nrf2, and it leads to the stimulated transcription of this gene and cisplatin resistance [77]. P53 is a gene with essential functions in the progression of various cancer types, such as breast cancer [78], colorectal cancer [79], and lung cancer [80].

On the other hand, lung cancer cells which have overexpression of the Nrf2/HO- 1 axis have downregulated expression of IL-1 $\beta$ and metallo-proteinases [57]. The activity status of NRF2 reported for various malignancies is shown in Table 1.

Table 1. The Nrf2 status and effect in different cancer types.

\begin{tabular}{|c|c|c|c|}
\hline Type of Cancer & Nrf2-Activated/Inhibited & Effect & Reference \\
\hline \multirow[t]{2}{*}{ Bladder cancer } & Activated & Cisplatin resistance & [81] \\
\hline & \multirow{6}{*}{ Activated } & $\begin{array}{l}\text { Increased resistance to taxol and } \\
\text { anchorage-independent growth }\end{array}$ & [82] \\
\hline \multirow[t]{5}{*}{ Breast cancer } & & $\begin{array}{c}\text { Increase as the disease progresses, leads to poor } \\
\text { prognostic (p62) }\end{array}$ & [83] \\
\hline & & $\begin{array}{l}\text { Upregulation leads to aromatase-induced drug } \\
\text { resistance }\end{array}$ & [84] \\
\hline & & Decreased sensitivity to photodynamic therapy (PDT) & [85] \\
\hline & & Cell proliferation and migration & [86] \\
\hline & & Enhanced glycolysis & [87] \\
\hline Cervical cancer & Activated & Drug resistance & [88] \\
\hline \multirow[t]{2}{*}{ Colon cancer } & Inhibited & $\begin{array}{l}\text { Epidermal Growth Factor (EGF) increases the } \\
\text { expression of Nrf2 }\end{array}$ & [89] \\
\hline & Activated & $\begin{array}{l}\text { 5-Fluorouracil resistance } \\
\text { Oxaliplatin resistance }\end{array}$ & {$[90,91]$} \\
\hline Gastric cancer & Activated & $\begin{array}{c}\text { Stimulates cancer progression in wild-type p53 cancers } \\
\text { Worse prognosis }\end{array}$ & [92-94] \\
\hline Glioblastoma & Activated & Radioresistance & [95] \\
\hline Glioma & Activated & Stimulates the cancer stem-cell phenotype & [96] \\
\hline \multirow[t]{2}{*}{$\begin{array}{l}\text { Hepatocellular } \\
\text { carcinoma }\end{array}$} & \multirow[t]{2}{*}{ Activated } & 5-Fluorouracil resistance & [97] \\
\hline & & $\begin{array}{l}\text { Supplies the substrates for glutathione and nucleotide } \\
\text { production }\end{array}$ & [71] \\
\hline \multirow{2}{*}{ Lung cancer } & \multirow{2}{*}{ Activated } & $\begin{array}{l}\text { Mutated p53 does not inhibit the promoter region of } \\
\qquad N r f 2 \text { gene }\end{array}$ & [77] \\
\hline & & Increased chemoresistance & {$[62,98]$} \\
\hline \multirow[t]{2}{*}{ Multiple myeloma } & \multirow[t]{2}{*}{ Activated } & $\begin{array}{l}\text { Regulates endoplasmic reticulum } \\
\text { (ER)-stress-associated apoptosis }\end{array}$ & [99] \\
\hline & & Malignant transformation & [100] \\
\hline \multirow[t]{2}{*}{ Pancreatic cancer } & \multirow[t]{2}{*}{ Activated } & Chemoresistance & [101] \\
\hline & & $\begin{array}{l}\text { Nrf2 activation counteracts the transforming growth } \\
\text { factor beta (TGF } \beta) \text { inhibition of premalignant lesions } \\
\text { in pancreatic cancer }\end{array}$ & [102] \\
\hline \multirow{2}{*}{ Prostate cancer } & \multirow{2}{*}{ Inhibited } & Promoter was found to be hypermethylated & [103] \\
\hline & & $\begin{array}{l}\text { Lowered the reactive oxygen species (ROS) in prostate } \\
\text { cancer (PCa) cells and sensitized PCa cells to radiation }\end{array}$ & [104] \\
\hline Ovarian cancer & Activated & $\begin{array}{c}\text { Resistance to methyl pyropheophorbide a-mediated } \\
\text { photodynamic therapy }\end{array}$ & [105] \\
\hline
\end{tabular}




\section{The Interplay between Nrf2 and Other Signaling Pathways}

The Keap1/Nrf2 pathway interacts with other signaling pathways, such as NF-kB, PI3K/Akt, Notch, MAPK, and Wnt Family Member 3AWNT-3A. These switch the tumor survival signal on and off as a result of Nrf2 activation or inhibition (see Table 2).

The mitogen-activated protein kinase kinase 1 (MAP2K1, alternative name MEK)/extracellular signal-regulated kinase (ERK) signaling pathway induces the nuclear accumulation of Nrf2. In human embryonic kidney cells, HEK-293, it was proven that the MEK/ERK signaling pathway interacts with Nrf2 through IQ Motif Containing GTPase Activating Protein 1 (IQGAP1) [106]. IQGAP1 functions as a tumor-promoting protein in breast cancer [107], glioma [108], and ovarian cancer [109].

The Nuclear factor kappa light chain enhancer of activated B cells (NF- $\mathrm{kB}$ ) signaling pathway promotes the expression of the pro-inflammatory cytokines TNF $\alpha$, IL-1, IL-6, and IL-8 [110], and its activation is involved in tumor promotion [111]. NF- $\mathrm{kB}$ is another signaling pathway with a dual role in cancer which induces DNA damage causing cell death; however, as cancer progresses, it establishes many cancer hallmarks, including resistance to chemotherapy [112]. Nrf2 counteracts the NF- $k B$ action through multiple mechanisms: stimulating the antioxidant genes, impairing the NF- $\mathrm{kB}$ signaling pathway, and inhibiting the production of pro-inflammatory cytokines [113].

Inhibitor of nuclear factor kappa-B kinase subunit beta (IKK $\beta$ ) is a member of the NF- $\mathrm{kB}$ signaling pathway that interacts with Keap1 and induces IKK $\beta$ ubiquitination. The Keap1 genomic locus is lost or mutated in cancer [114]. The p65 protein competes with the cAMP response element-binding protein (CREB)-binding protein (CBP) for binding to ARE and impairs binding of CBP to ARE. P65 also interacts with histone deacetylase 3 (HDAC3) and causes the histone hypoacetylation of ARE. P65 overexpression is induced by NF- $\mathrm{KB}$ signaling [115]. MAF bZIP transcription factor K (MafK) forms a complex with CBP and Nrf2 that stimulates the transcription of several genes. This protein, however, also mediates the recruitment of p65 and NF- $\mathrm{kB}$ to the promoters of IL-8 and TNF $\alpha$ [116].

The PI3K/Akt/mechanistic target of rapamycin kinase (mTOR) signaling pathway promotes cancer cell proliferation and survival [117], especially through its essential role in cell-cycle progression [118]. Nrf2 was associated with the stimulation of the platelet-derived growth factor A (PDGFA) by recruiting specific proteins to its promoter. It also activates the Akt/p21 pathway, which leads to cell-cycle progression [119].

Nrf2 also leads to the increased transcription of the proliferating cell nuclear antigen (PCNA) gene and the activation of the Notch signaling pathways, which augments the cellular level of NOTCH1 intracellular domain (NICD1) and Hes Family BHLH Transcription Factor 1 (HES1) genes, leading to enhanced proliferation of oral squamous cell carcinoma cells [120].

P38 MAP kinase (MAPK) activation leads to the turning on of Nrf2, which resulted in acquired resistance to temozolomide in glioma cells [121]. 
Table 2. The interaction between Nrf2 and other signaling pathways.

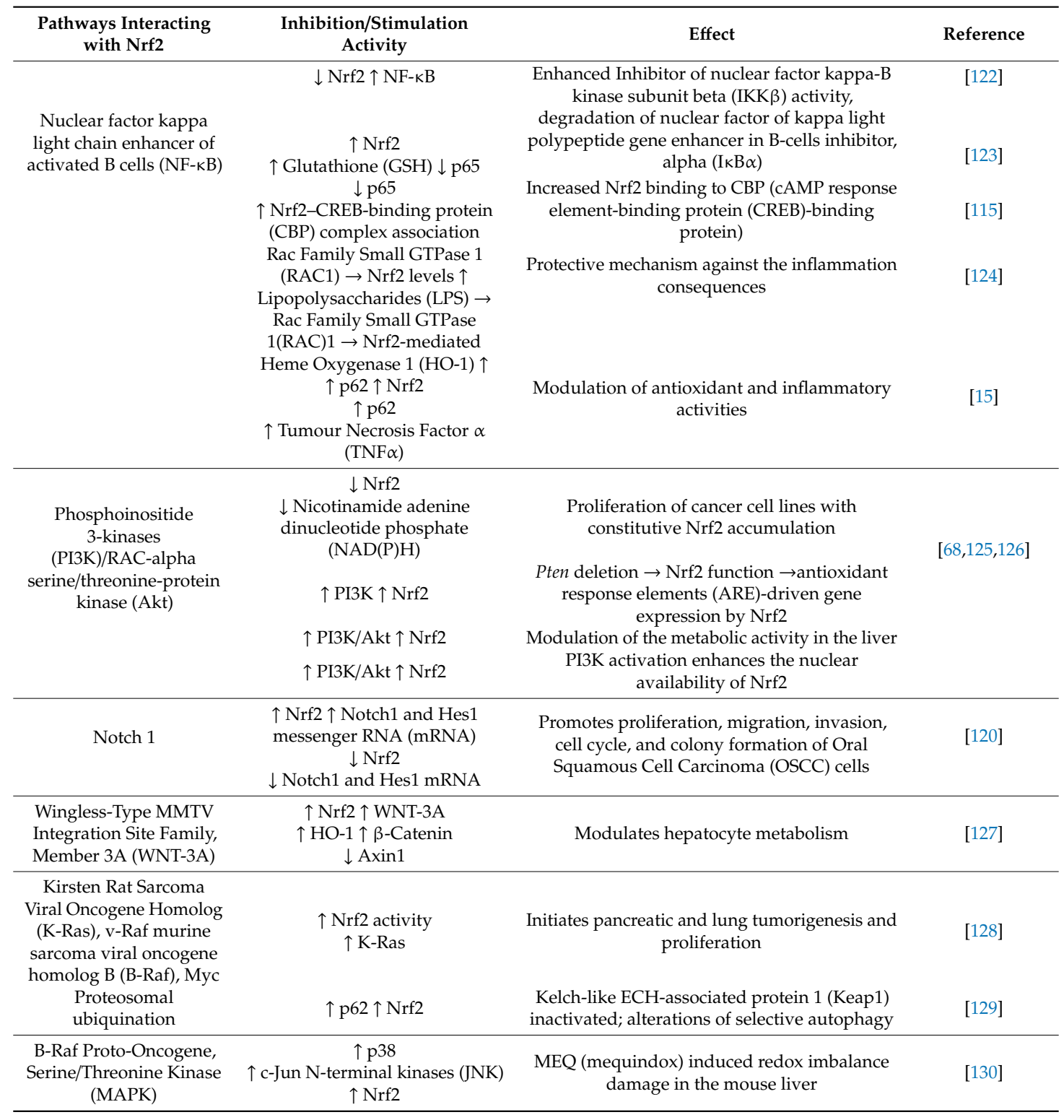

\section{The microRNA Regulation of Nrf2 Signaling Pathway in Cancer}

MicroRNAs (miRNAs) are a type of non-coding RNA with a length of 19-25 nt [131] which can repress the translation of mRNA into protein and can target multiple types of mRNAs [132]. In cancer, microRNAs can either be overexpressed and promote cancer progression or underexpressed and inhibit cancer progression [133,134], and they are important regulators of multidrug resistance [135]. All microRNAs that target not only Nrf2 but also Keap1 and other proteins involved in the cell response to oxidative stress are called redox miRs [43].

MiR-432 is an oncomiR involved in the cisplatin resistance of cancerous cells, and it binds to the coding region of the Keap1 transcript. This is followed by the inhibition of Keap1-Nrf2 interaction and the activation of Nrf2 [136].

In bronchial epithelial cells exposed to arsenic, the level of miR-155 increased, and Nrf2 translation was inhibited [137]. Nrf2 translation is also repressed by miR-144-3p in the peripheral blood and bone marrow of acute myeloid leukemia (AML) patients. MiR-144-3p is overexpressed in HL-60 cells, and it is involved in apoptosis resistance and cell viability promotion [138]. MiR-28 binds to the 3' untranslated region (UTR) of Nrf2 and suppresses the mRNA ribosomal translation. This is a direct 
binding and does not impair the Nrf2-Keap1 interaction [139]. MiR-148b inhibits Nrf2 expression by down regulating ERMPI expression [140].

In breast cancer, the silencing of Nrf2 leads to the activation of the NF- $\mathrm{kB}$ signaling pathway and the overexpression of miR-181c. This miRNA inhibits the mitochondrial production of cytochrome $\mathrm{c}$ oxidase, the mitochondrial potential maintenance, and oxygen consumption [141].

Because Nrf2 is a transcription factor, it can also induce the transcription of several microRNAs by binding to the promoter region of the encoding DNA sequence. These targeted miRNAs include miR-193b, miR-365, miR-617, miR-592, miR-1207, miR-32, miR-200c, and miR-550 [142]. Nrf2 induces the transcription of HO-1, which in turn downregulates the activity of DiGeorge Syndrome Critical Region Gene 8 (DGCR8), and it is involved in miRNA biogenesis. The microRNAs regulated by Nrf2 can have a feedback loop response and regulate their transcription. MiR-27a, miR-142-5p, miR-144, and miR-153 downregulate Nrf2 production in a Keap1-dependent mechanism. MiR-21 is also a generally regarded oncomiR with key functions in inflammation, and, by being a downstream effector of the TGF $\beta$-initiated pathway, it is also involved in the epithelial-to-mesenchymal transition. MiR-155 is involved in cytokine production in cancerous cells [143]. Nrf2 opposed the TGF $\beta / m i R-21$ activity in alcohol-treated lung fibroblasts [144].

In mucoepidermoid lung carcinoma (MEC), Nrf2 overexpression was correlated with HO overexpression, and it led to MMP12 and MMP9 downregulation. Nrf2 production was positively correlated with miR-181a, miR-193b, and miR-424 and negatively associated with miR-378 [57].

During the process of carcinogenesis, miR-365-1, miR-193b, miR-28, miR-93, miR-153, miR-27a, miR-142-5p, and miR-144 are downregulated. This underexpression leads to the upregulation of their target, Nrf2 mRNA, and the stimulated phosphorylation and activity of this transcription factor. Nrf2 overstimulation results in increased cell survival, sustained tumorigenesis, and enhanced tumor growth. This is followed by an increased miR-125b1 and decreased miR-29-b1 expression level, which offers chemoresistance. During chemotherapy, ROS levels are also increased, as well as miR-141 and miR-340 expression level, which suppress the phosphorylation of Nrf2. MiR-200a is decreased during carcinogenesis, which inhibits the formation of the Nrf2-Keap1-Cul3 complex [145]. MiR-200a was found to target Keap1 mRNA and, thus, release Nrf2 from the cytoplasm entrapment [146,147]. Nrf2 and miR-200a overexpression also promotes dendritic cell maturation [148].

In lung fibroblasts exposed to radiation, the BRCA1 level is increased, which elevates Nrf2 nuclear import, as well as decreasing the Keap1 level. Nrf2, once in the nucleus, promotes the transcription of miR-140, which results in impaired self-renewal ability, increased cell migration, and higher contractile capabilities [149].

An in vitro experiment proved that, in hepatocellular carcinoma, miR-141 is overexpressed, leading to Keap1 underexpression and, consequently, Nrf2 nuclear accumulation. This TF binds to the promoter region of the HO-1 gene by increasing this gene product and triggers an elevated 5-fluorouracil resistance [97]. In the same cancer type, it was proven that miR-340 is downregulated, and its target Nrf2 is upregulated. Nrf2 overexpression confers cisplatin resistance to hepatocellular carcinoma cells through its antioxidant activity [150].

The feedback regulation between Nrf2 and its miRNA targets was also revealed in AML cells. Through Keap1 silencing, miR-125b was upregulated, and miR-29b was downregulated by Nrf2 in AML. It was further proven that the Nrf2 binds to the 5' UTR DNA region of miR-125b and downstream of miR-29b. The altered expression of these two microRNAs results in leukemic cell survival after chemotherapy treatment [151].

In mouse keratinocytes, Nrf2 activation leads to the overstimulated transcription of miR-29a/b by Nrf2 bonding to the promoter region of the MiR-29ab1 gene. Nrf2 also leads to changes in epidermal desmosomes [152].

Metformin, an antidiabetic drug repositioned for cancer [153], induces Sirtuin 1 (SIRT) downregulation only in p53 wild-type cancer cells. This results in the upregulation of p53 and miR-34a, followed by a decreased level of Nrf2 and PPAR $\gamma$ transcriptional activity [154]. 
In human leukemic cells, Mitogen-activated protein kinase 7 (MAPK7, also known as ERK5) and Myocyte Enhancer Factor 2 (MEF2) are phosphorylated in response to oxidative stress. MEF2 enters the nucleus, where it stimulates the transcription of miR-23a. This microRNA represses the translation of Keap1 in the cytoplasm [155].

The multi level regulation of Keap1-Nrf2 signaling pathway by microRNAs is illustrated in Figure 2.

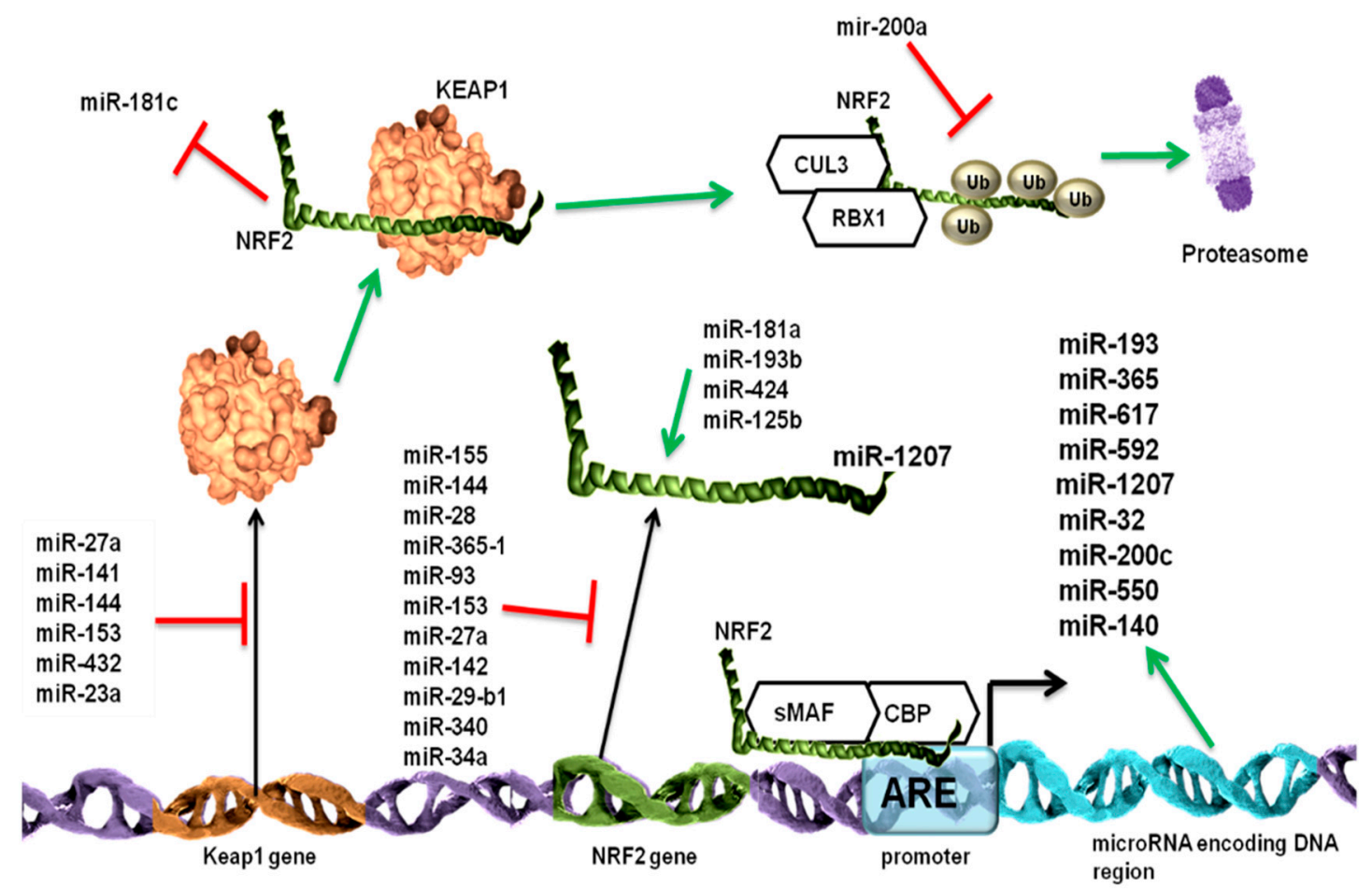

Figure 2. The Nrf2 pathway is regulated at multiple levels by different microRNAs. The Nrf2 pathway has two important players: the Nrf2 transcription factor and its inhibitor, the Kelch-like ECH-associated protein 1 (Keap1) protein. The Nrf2 interaction with Keap1 leads to the further binding of Cullin 3 (Cul3) and RING-box protein 1 (Rbx1) proteins and the ubiquitination of Nrf2 proteins, resulting in proteasomal degradation. If Nrf2 does not bind to Keap1, it binds to the antioxidant response element (ARE)-containing promoter regions, and, by forming a complex with small V-Maf Avian Musculoaponeurotic Fibrosarcoma Oncogene (sMaf) and cAMP response element-binding protein (CREB)-binding protein (CBP), it leads to the further activated transcription of its targeted genes. MicroRNAs suppress Keap1/Nrf2 signaling at multiple levels. MiR-27a, miR-141 miR-144, miR-153, miR-200a, miR-432, and miR-23a repress the translation of Keap1 messenger RNA (mRNA), thus allowing for Nrf2 activation. MiR-155, miR-144, miR-28, miR-365-1, miR-93, miR-153, miR-27a, miR-142, miR-29-b1, miR-340, and miR-34a, either through direct repression of Nrf2 mRNA in a Keap1-independent manner or by enhancing the Keap1 cellular level, inhibit Nrf2 activity. MiR-181a, miR-193b, miR-424, and miR-125b stimulate Nrf2 activation most probably by repressing its activators. The Keap-Nrf2 interaction leads to the repression of miR-181c, which is involved in the Nuclear factor kappa light chain enhancer of activated B cells (NF-kB) signaling pathway. MiR-200a inhibits the ubiquitination of $\mathrm{Nrf2}$, thus protecting it from degradation. Nrf2, in addition to the classical targeted genes, can also stimulate the expression of the miRNA-encoding DNA region. The Keap1 protein structure was taken from the http://www.rcsb.org database [156,157] and the Nrf2 structure was taken from the http://www.cisreg.ca/tfe/structures/NFE2L2-4780-1jnmB.pdb.png online tool. 


\section{Examples of Nrf2 Application in Evaluating Therapy Response}

Throughout our review, we analyzed the protective role of Nrf2 in the case of cancer, which leads to a weaker treatment response. In lung cancer, it was proven in vitro that A549 cells transfected with Nrf2siRNA were more prone to cell death as a response to radiotherapy than the control A549 cells [158]. At the same time, as Tian et al. pointed out, it should be considered that Nrf2 also protects healthy cells from radiation-induced inflammation and a rise in oxidative stress [159]. The radiotherapy action is mediated mainly by enhancing the intracellular oxidative stress. The cancer stem cells gain radioresistance by activating DNA repair mechanisms, diminishing ROS level with the help of stimulated glutathione biosynthesis, activating anti-apoptotic pathways, and decreasing the intratumoral hypoxia [160]. Ionizing radiation induces the overexpression of Nrf2-targeted genes and offers radioresistance [161]. This can constitute the basis for developing new therapeutic strategies in cancer that are based on nanoscale targeted delivery of cytotoxic drugs [162,163].

Our analysis of TCGA data is meant to be proof of concept, which we used to prove that gene expression analysis in regard to Nrf2signaling pathways should not be so heavily focused on the expression of Keap1-Nrf2 mRNA expression, but also on the expression of their targeted genes.

In order to observe the consequences following Nrf2 activation in lung cancer tissue exposed to radiation therapy, we extracted clinical data and RNA-sequencing (RNA-Seq) data of lung adenocarcinoma (LUAD) from TCGA, which included 173 samples for which there was information regarding radiation therapy status. The clinical data selected for our analysis included qualitative values describing whether the patients went through radiation therapy or not. From the RNA-Seq dataset, we looked only at the genes whose transcription is induced by Nrf2, resulting in a total of 117 genes (and gene variants) (the list was taken from Reference [164], and for every gene all gene variants were searched for in the database) (see File S1, Supplementary Materials). Based on radiation therapy status, the dataset was divided into patients who received initial radiation therapy or not those who received and new radiation therapy or not. Additional radiation therapy is applied in the case of LUAD recurrence or progression of disease after initial therapy. We compared patients going through radiation therapy and those who did not go through radiation therapy by applying the non-parametric Mann-Whitney test.

In LUAD tissue samples from patients who initially received radiation therapy, we found only two genes, Glutathione S-Transferase Omega 1 and Sulfotransferase Family 2B Member 1 (from a total of 117 Nrf2-targeted genes), which were upregulated in the case of radiotherapy versus non-recipients of this kind of therapy (Figure 3). In LUAD tissue samples from patients who received initial radiation therapy, we found only one Nrf2targeted gene, Methylenetetrahydrofolate Dehydrogenase (NADP+ Dependent) 2, which was upregulated in the case of additional radiotherapy versus non-recipients of this kind of additional therapy. At the same time, nine genes were downregulated in the case of radiotherapy versus non-recipients of this kind of therapy (Figure 4). These genes were Alcohol Dehydrogenase 1A $(A D H 1 A)$, Aldehyde Dehydrogenase 3 Family Member A1 (ALDH3A1), Aldehyde Dehydrogenase 3 Family Member A2 (ALDH3A2), Alcohol Dehydrogenase 1B (ADH1B), Glutathione Peroxidase 2 (GPX2), Alcohol Dehydrogenase 1C (ADH1C), Aldehyde Dehydrogenase 6 Family Member A1 (ALDH6A1), Aldo-Keto Reductase Family 1 Member C3 (AKR1C3), and NAD(P)H Quinone Dehydrogenase 1 (NQO1) (from a total of 117 Nrf2 targeted genes) All of these genes are involved in redox reactions.

The data used to look at the gene expression of each targeted gene affected by radiation therapy described in this manuscript were obtained from the GTEx Portal (https://gtexportal.org) on 31 October 2019. The survival analysis was done with the help of the RTCGA package and the maxstat (maximally selected rank statistics) package to determine the cutoff for each gene in $\mathrm{R}$ (Figure 5). From the total genes targeted by Nrf2 and affected by radiation therapy in lung cancer, we illustrated only seven genes with a statistically significant contribution to overall survival (log-rank, $p<0.05)$. These were Glutathione S-Transferase Omega 1 (GSTO1), Sulfotransferase Family 2B Member 1 (SULT2B1), ADH1A, $A L D H 3 A 2, A D H 1 B, A D H 1 C$, and Methylenetetrahydrofolate Dehydrogenase (NADP+ Dependent) 2, Methenyltetrahydrofolate Cyclohydrolase (MTHFD2) (Figure 5). Nrf2 (NFE2L2 gene) has no statistically 
significant influence in overall survival in lung cancer; however, the lung is the tissue with top NFE2L2 expression (Figure 6). We also checked the expression of these genes in cancer tissue, especially lung cancer, with the help of the gepia online tool (http://gepia.cancer-pku.cn/index.html) [165], with a $\log 2 \mathrm{FC}$ cutoff of 1 , and matched the TCGA normal and GTEx data. Glutathione S-Transferase Omega 1 (GSTO1), Sulfotransferase Family 2B Member 1 (SULT2B1), ADH1A, ADH1B, and ADH1C were downregulated in lung cancer versus normal tissue, while $A L D H 3 A 2$ and MTHFD2 were upregulated in lung cancer tissue versus normal adjacent tissue.

The genes were then inserted in the Gene String online tool (https://string-db.org/), where the outliers were excluded from the central network (Figure 7); the function of these genes was also taken from the Gene String database (Table 3).
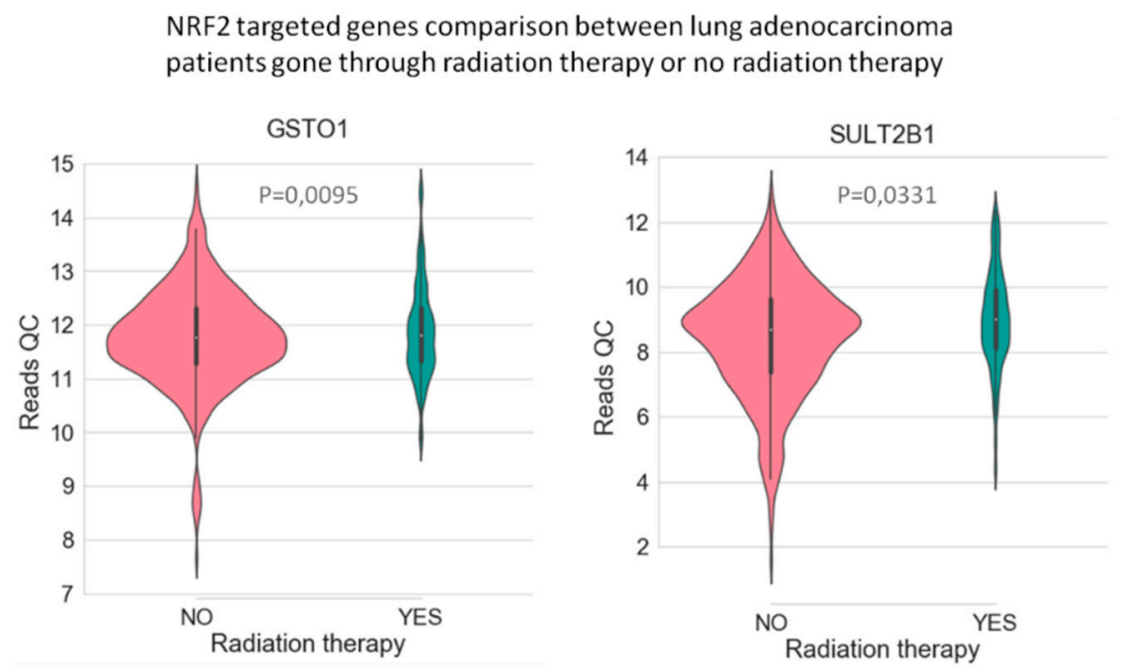

Figure 3. The Nrf2-targeted genes GSTO1 and SULT2B1 are upregulated in lung cancer tissue from patients who went through initial radiation therapy. The $p$-value was calculated with the help of the Mann-Whitney statistical test. 
Nrf2-targeted gene comparison between lung adenocarcinoma patients who went through addition radiation therapy or not.

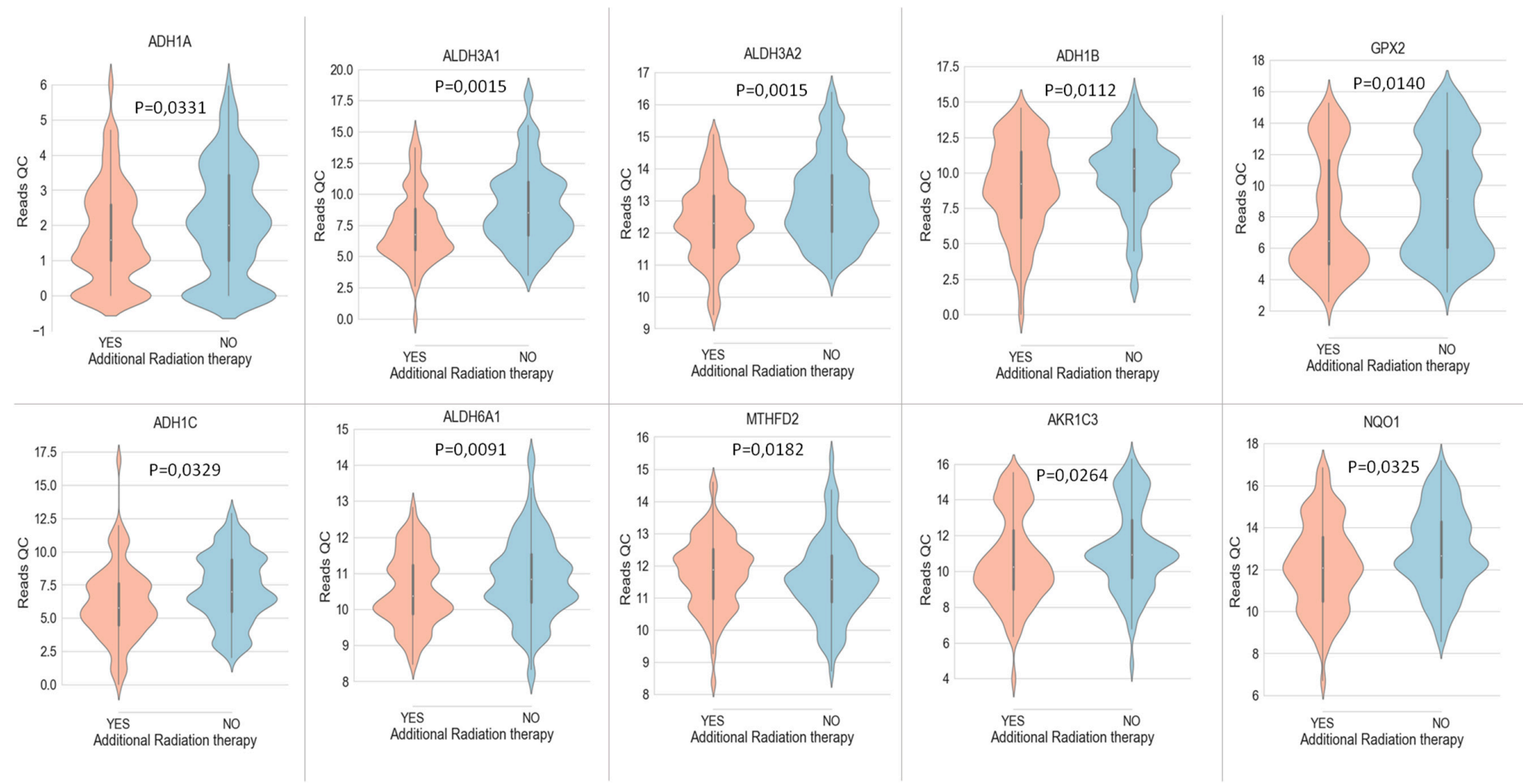

Figure 4. The Nrf2-targeted genes MTHFD2 is upregulated in lung cancer tissue from patients who went through additional radiation therapy, while there are nine Nrf2-targeted genes which are downregulated in the case of additional radiation therapy: ADH1A, ALDH3A1, ALDH3A2, ADH1B, GPX2, ADH1C, ALDH6A1, AKR1C3, and NQO1. The $p$-value was calculated with the help of the Mann-Whitney statistical test. 

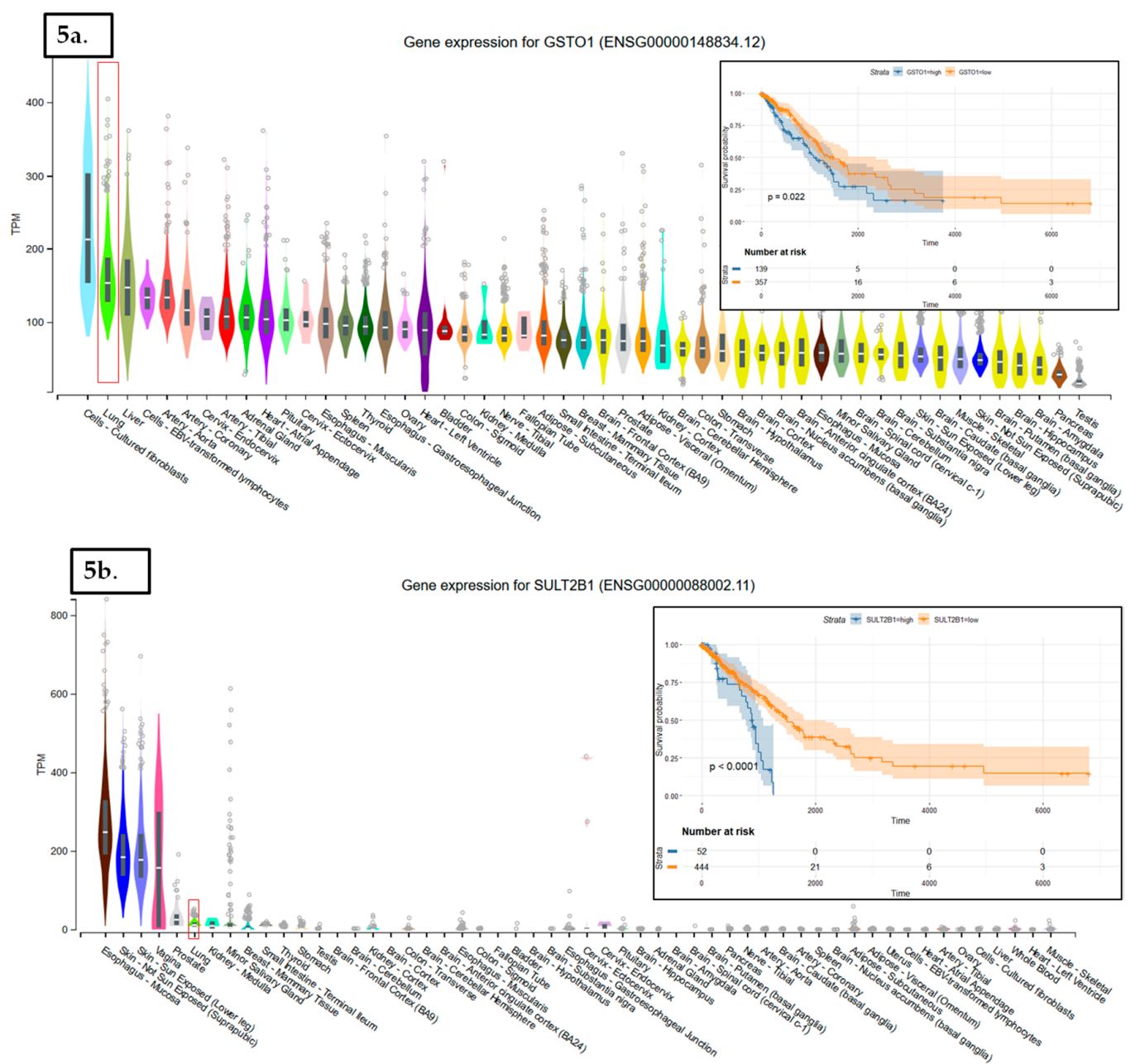

5c. Gene expression for ADH1A (ENSG00000187758.7)

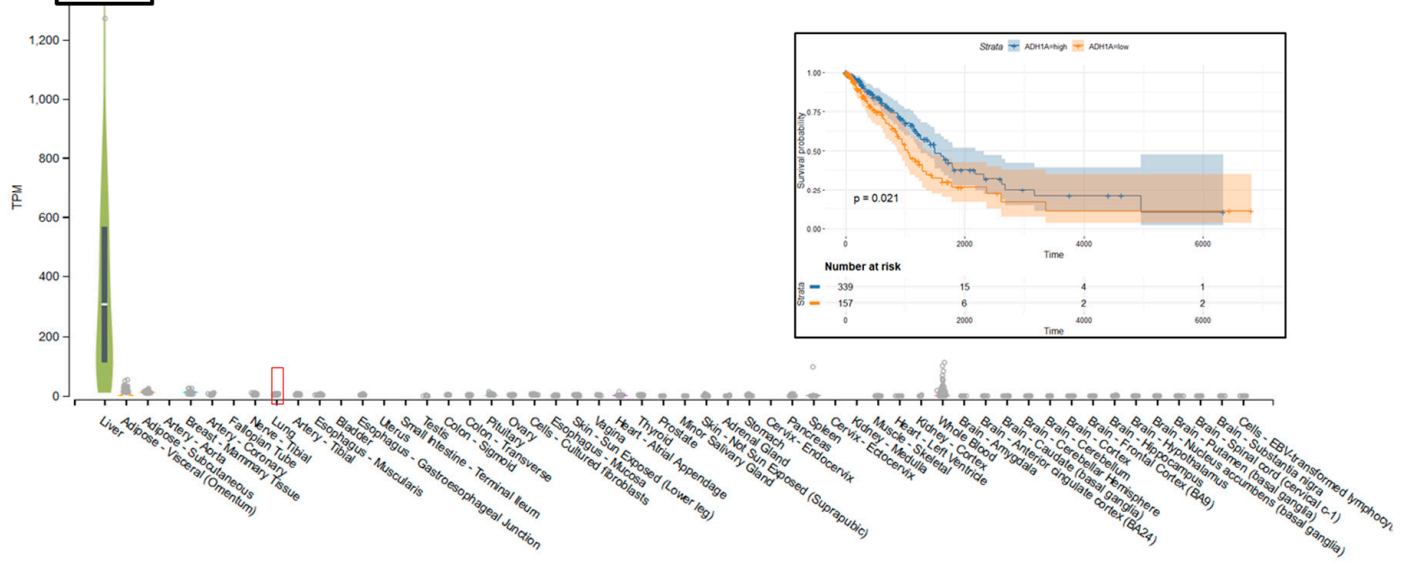

Figure 5. Cont. 

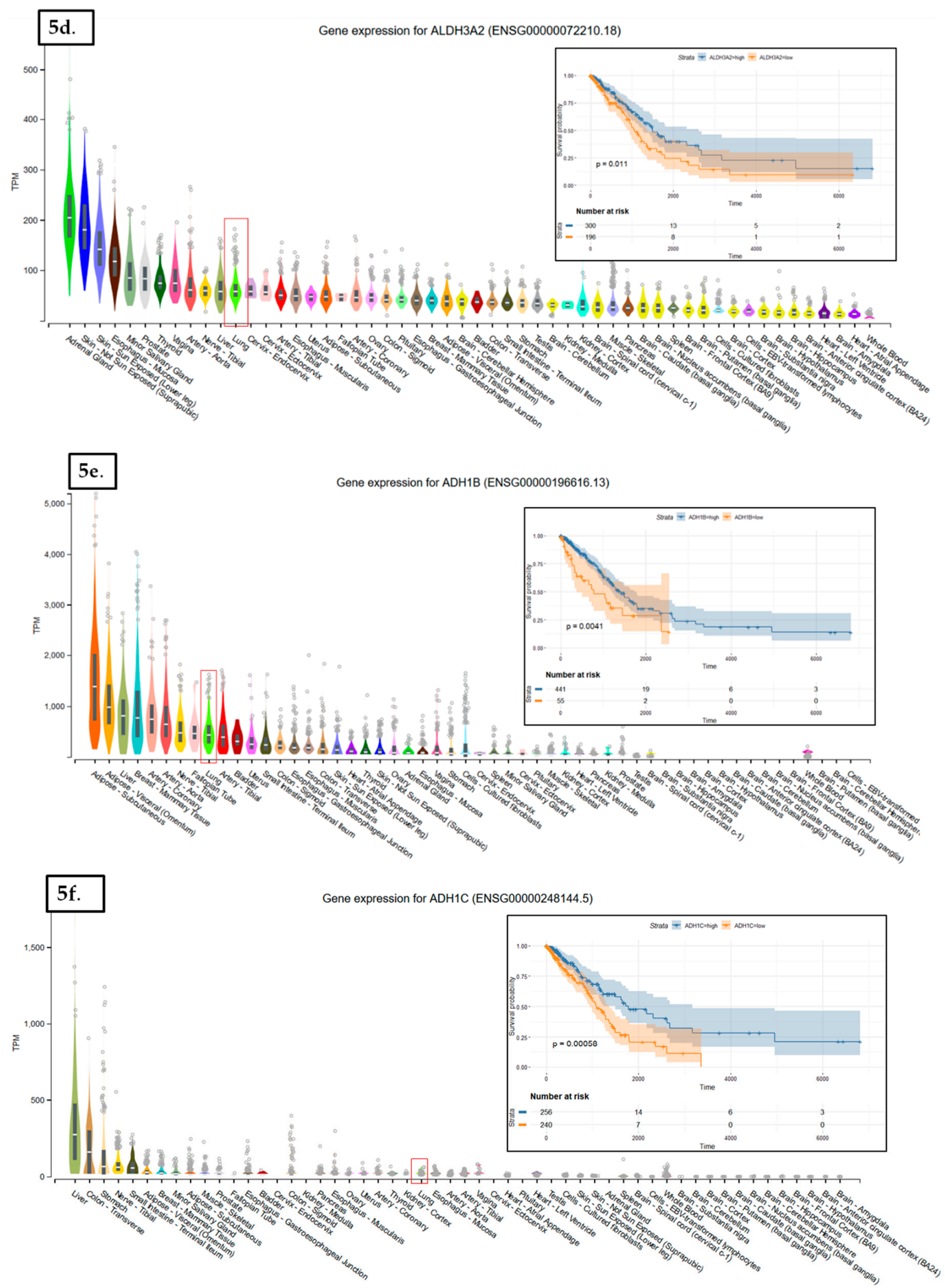

Figure 5. Cont. 


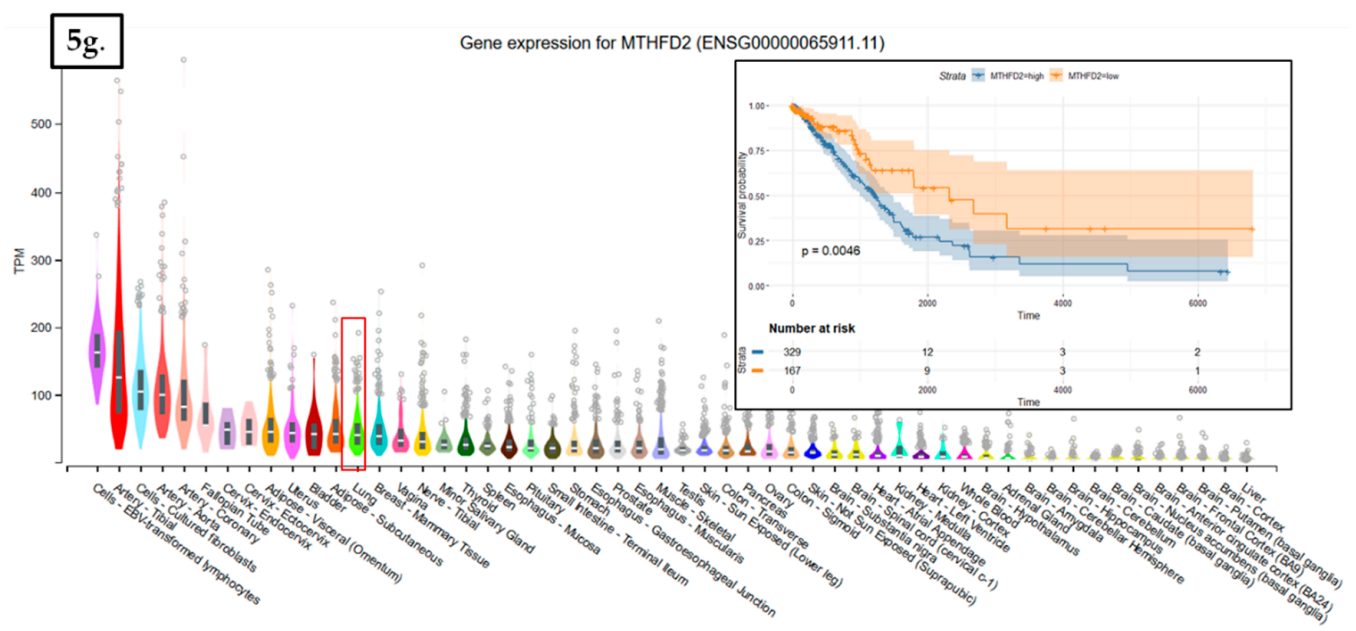

Figure 5. The tissue distribution and Kaplan-Meier (KM) plots of Nrf2-targeted genes affected by radiation therapy and whose expression affects the overall survival of lung cancer patients. These genes are GSTO1 (a), SULT2B1 (b), ADH1A (c), ALDH3A2 (d), ADH1B (e), ADH1C (f), and MTHFD2 (g). The expression of each gene in the lung normal tissue is marked by a red square. GSTO1 (a), SULT2B1 (b), $A D H 1 A(\mathbf{c}), A D H 1 B(\mathbf{e})$, and $A D H 1 C$ (f) are downregulated in lung cancer versus normal tissue; $A L D H 3 A 2(\mathbf{d})$ and MTHFD2 (g) are upregulated in lung cancer tissue versus normal adjacent tissue. On KM plots, groups with high expression are shown in blue, and groups with low expression are shown in red.

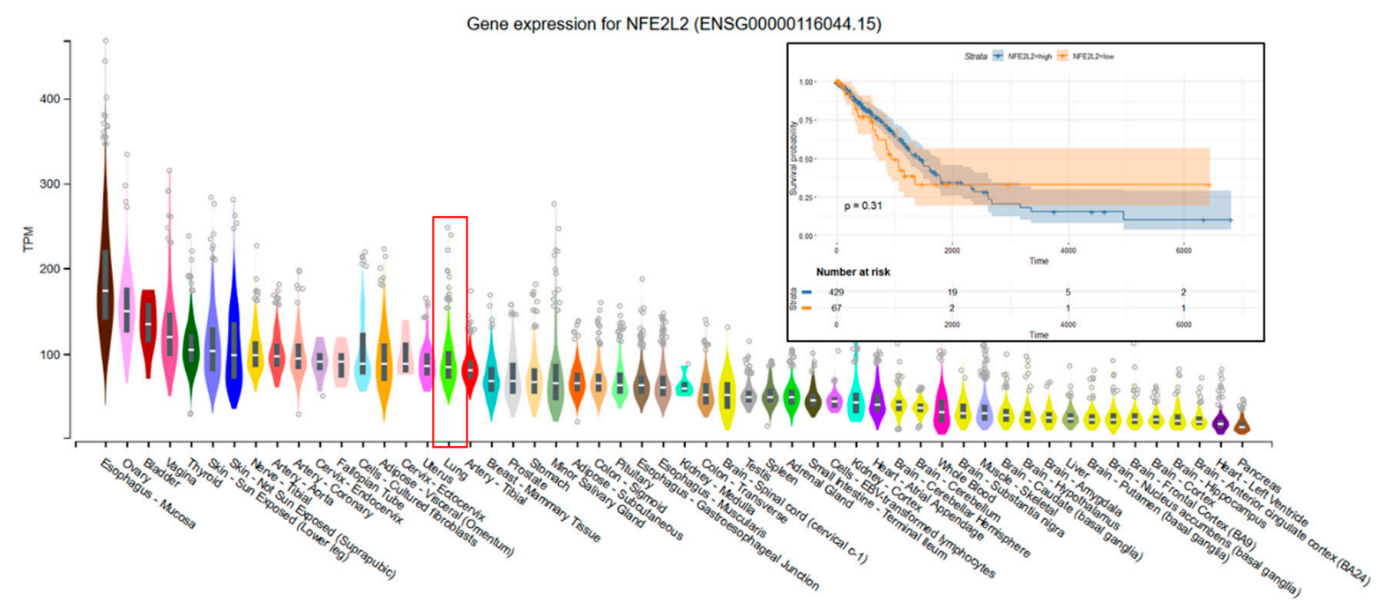

Figure 6. The tissue distribution and Kaplan-Meier plots of the Nrf2 gene (NFE2L2). The expression of each gene in the lung normal tissue is marked by a red square. On KM plots, groups with high expression are shown in blue, and groups with low expression are shown in red. The expression of the NFE2L2 gene at the mRNA level has no significant effect on the overall survival of lung cancer patients. 


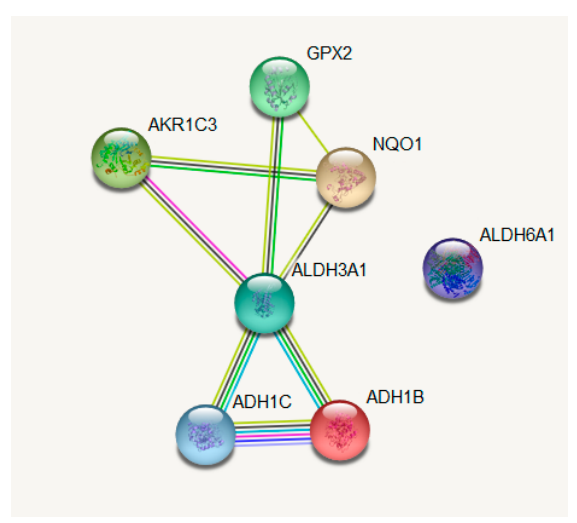

Figure 7. Interaction map of the Nrf2-targeted genes which show differential expression between lung adenocarcinoma (LUAD) patients who went through additional radiation therapy or not. The network was built with the help of the Gene String online tool (https://string-db.org/) [166].

Table 3. List of Nrf2-targeted genes and their function. The list was constructed with the help of the Gene String online tool (https://string-db.org/) [166].

\begin{tabular}{|c|c|}
\hline Name & Biological Function \\
\hline$A D H 1 B$ & Belongs to the zinc-containing alcohol dehydrogenase family. \\
\hline NQO1 & $\begin{array}{l}\text { The enzyme is apparently involved in detoxification pathways, as well as in the } \\
\text { biosynthetic vitamin K-dependent gamma-carboxylation of glutamate residues in } \\
\text { prothrombin synthesis. }\end{array}$ \\
\hline AKR1C3 & $\begin{array}{c}\text { Catalyzes the conversion of aldehydes and ketones to alcohols. Catalyzes the } \\
\text { reduction of prostaglandin (PG) D2, PGH2, and phenanthrenequinone (PQ) and } \\
\text { the oxidation of 9-alpha, 11-beta-PGF2 to PGD2. Preferentially transforms } \\
\text { androstenedione (4-dione) to testosterone. }\end{array}$ \\
\hline GPX2 & $\begin{array}{c}\text { Could play a major role in protecting mammals from the toxicity of ingested } \\
\text { organic hydroperoxides. tert-Butyl hydroperoxide, cumene hydroperoxide, and } \\
\text { linoleic acid hydroperoxide can act as acceptors. }\end{array}$ \\
\hline$A L D H 3 A 1$ & $\begin{array}{l}\text { Plays a major role in the detoxification of alcohol-derived acetaldehyde. Involved } \\
\text { in the metabolism of corticosteroids, biogenic amines, neurotransmitters, and } \\
\text { lipid peroxidation. }\end{array}$ \\
\hline ADH1C & Alcohol dehydrogenase. \\
\hline$A L D H 6 A 1$ & $\begin{array}{c}\text { Plays a role in valine and pyrimidine metabolism. Binds fatty acyl-CoA; aldehyde } \\
\text { dehydrogenases. }\end{array}$ \\
\hline
\end{tabular}

\section{Conclusions}

Nrf2 was suggested as a possible therapeutic target. Nrf2 implication in cancer remains controversial due to its protection of normal and cancerous cells. Nrf2 can be regarded as a simple response element to the signals initiated by an external factor or via its intersection with different regulatory mechanisms inside the cell. Nrf2 activation protects normal cells from malignant transformation, especially in the case of bronchial epithelial cells. At the DNA level, methylation in the Keap1 promoter, epigenetic silencing of its targeted genes, or mutations present in the binding sites of Keap1-Nrf2 take place during cancer development, but also under selective pressure of different therapies.

MicroRNAs can control the Nrf2 signaling pathway at different levels: repression of Keap1 by miR-27a, miR-141, miR-144, miR-153, miR-200a, miR-432, and miR-23a; repression of Nrf2 by miR-155, miR-144, miR-28, miR-365-1, miR-93, miR-153, miR-27a, miR-142, miR-29-b1, miR-340, and miR-34a; and the indirect activation of Nrf2 by miR-181a, miR-193b, miR-424, and miR-125b. Also, it is worth mentioning that the TCGA data revealed the fact that Nrf2 activation is not universal.

For instance, in the case of recurrent disease and radiotherapy, we observed that, for the majority of Nrf2-targeted genes, there is no change in expression level. This proves that the universal, axiomatic 
rationale that Nrf2 is activated as a response to chemo- and radiation therapy is wrong, and that each scenario should be carefully evaluated with the help of Nrf2-targeted genes. There were nine genes involved in lipid peroxidation, which showed underexpression in the case of additional radiation therapy. In addition to this, we consider that it makes more sense and it will have greater scientific value if future research on $\mathrm{Nrf2}$ activation/inhibition in different scenarios is evaluated not through the evaluation of Keap1-Nrf2 mRNA expression, but through the mRNA expression of their targeted genes. It is also important to analyze the targeted genes at the post-transcriptional level, not the post-translational or protein levels, since there can be other inhibitory molecular mechanisms interfering in gene expression.

Supplementary Materials: The following are available online at http://www.mdpi.com/2072-6694/11/11/1755/s1, Table S1: Full list of Nrf2 targets included in our analysis.

Funding: This work was supported by the Funding Agency-Ministry of Research and Innovation through the doctoral research project "Characterization of the molecular profile of hormone-dependent tumors" PCD—no. 1530/63/18 January 2018, by the Funding Agency-Ministry of Research and Innovation, through the project PNCDI III 2015-2020 "Increasing the performance of scientific research and technology transfer in translational medicine through the formation of a new generation of young researchers"-ECHITAS, no.29PFE/18.10.2018, and by the Funding Agency-Ministry of Research and Innovation through CNFIS-FDI (CNFIS-FDI-2019-0666), entitled "Sustenance and valorification of research of excellence in the domain of personalized medicine by internationalization and incensement of research activities visibility."

Conflicts of Interest: The authors declare no conflicts of interest.

\section{References}

1. Petric, R.C.; Braicu, C.; Raduly, L.; Zanoaga, O.; Dragos, N.; Monroig, P.; Dumitrascu, D.; Berindan-Neagoe, I. Phytochemicals modulate carcinogenic signaling pathways in breast and hormone-related cancers. OncoTargets Ther. 2015, 8, 2053-2066. [CrossRef]

2. Blagotinsek, K.; Rozman, D. Targeting Signalling Pathways in Hepatocellular Carcinoma. Curr. Pharm. Des. 2017, 23, 170-175. [CrossRef]

3. Prahallad, A.; Bernards, R. Opportunities and challenges provided by crosstalk between signalling pathways in cancer. Oncogene 2016, 35, 1073-1079. [CrossRef]

4. Strom, J.; Xu, B.; Tian, X.; Chen, Q.M. Nrf2 protects mitochondrial decay by oxidative stress. J. Off. Publ. Fed. Am. Soc. Exp. Biol. 2016, 30, 66-80. [CrossRef]

5. Yagishita, Y.; Fukutomi, T.; Sugawara, A.; Kawamura, H.; Takahashi, T.; Pi, J.; Uruno, A.; Yamamoto, M. Nrf2 protects pancreatic beta-cells from oxidative and nitrosative stress in diabetic model mice. Diabetes 2014, 63, 605-618. [CrossRef]

6. Noel, S.; Martina, M.N.; Bandapalle, S.; Racusen, L.C.; Potteti, H.R.; Hamad, A.R.; Reddy, S.P.; Rabb, H. T Lymphocyte-Specific Activation of Nrf2 Protects from AKI. J. Am. Soc. Nephrol. 2015, 26, 2989-3000. [CrossRef]

7. Moi, P.; Chan, K.; Asunis, I.; Cao, A.; Kan, Y.W. Isolation of NF-E2-related factor 2 (Nrf2), a NF-E2-like basic leucine zipper transcriptional activator that binds to the tandem NF-E2/AP1 repeat of the beta-globin locus control region. Proc. Natl. Acad. Sci. USA 1994, 91, 9926-9930. [CrossRef]

8. Sykiotis, G.P.; Bohmann, D. Stress-activated cap'n'collar transcription factors in aging and human disease. Sci. Signal 2010, 3, re3. [CrossRef]

9. Canning, P.; Sorrell, F.J.; Bullock, A.N. Structural basis of Keap1 interactions with Nrf2. Free Radic. Biol. Med. 2015, 88, 101-107. [CrossRef]

10. Huang, Y.; Li, W.; Su, Z.Y.; Kong, A.N. The complexity of the Nrf2 pathway: Beyond the antioxidant response. J. Nutr. Biochem. 2015, 26, 1401-1413. [CrossRef]

11. Jiang, T.; Harder, B.; de la Vega, M.R.; Wong, P.K.; Chapman, E.; Zhang, D.D. p62 links autophagy and Nrf2 signaling. Free Radic. Biol. Med. 2015, 88, 199-204. [CrossRef] [PubMed]

12. Jain, A.; Lamark, T.; Sjottem, E.; Larsen, K.B.; Awuh, J.A.; Overvatn, A.; McMahon, M.; Hayes, J.D.; Johansen, T. p62/SQSTM1 is a target gene for transcription factor NRF2 and creates a positive feedback loop by inducing antioxidant response element-driven gene transcription. J. Biol. Chem. 2010, 285, 22576-22591. [CrossRef] [PubMed] 
13. Chen, W.; Sun, Z.; Wang, X.J.; Jiang, T.; Huang, Z.; Fang, D.; Zhang, D.D. Direct interaction between Nrf2 and p21(Cip1/WAF1) upregulates the Nrf2-mediated antioxidant response. Mol. Cell 2009, 34, $663-673$. [CrossRef] [PubMed]

14. Tilija Pun, N.; Park, P.H. Role of p62 in the suppression of inflammatory cytokine production by adiponectin in macrophages: Involvement of autophagy and p21/Nrf2 axis. Sci. Rep. 2017, 7, 393. [CrossRef]

15. Ichimura, Y.; Waguri, S.; Sou, Y.S.; Kageyama, S.; Hasegawa, J.; Ishimura, R.; Saito, T.; Yang, Y.; Kouno, T.; Fukutomi, T.; et al. Phosphorylation of p62 activates the Keap1-Nrf2 pathway during selective autophagy. Mol. Cell 2013, 51, 618-631. [CrossRef]

16. Moon, E.J.; Giaccia, A. Dual roles of NRF2 in tumor prevention and progression: Possible implications in cancer treatment. Free Radic. Biol. Med. 2015, 79, 292-299. [CrossRef]

17. Na, H.K.; Surh, Y.J. Oncogenic potential of Nrf2 and its principal target protein heme oxygenase-1. Free Radic. Biol. Med. 2014, 67, 353-365. [CrossRef]

18. Tebay, L.E.; Robertson, H.; Durant, S.T.; Vitale, S.R.; Penning, T.M.; Dinkova-Kostova, A.T.; Hayes, J.D. Mechanisms of activation of the transcription factor Nrf2 by redox stressors, nutrient cues, and energy status and the pathways through which it attenuates degenerative disease. Free Radic. Biol. Med. 2015, 88, 108-146. [CrossRef]

19. Hochmuth, C.E.; Biteau, B.; Bohmann, D.; Jasper, H. Redox regulation by Keap1 and Nrf2 controls intestinal stem cell proliferation in Drosophila. Cell Stem Cell 2011, 8, 188-199. [CrossRef]

20. Vomhof-Dekrey, E.E.; Picklo Sr, M.J. The Nrf2-antioxidant response element pathway: A target for regulating energy metabolism. J. Nutr. Biochem. 2012, 23, 1201-1206. [CrossRef]

21. Digaleh, H.; Kiaei, M.; Khodagholi, F. Nrf2 and Nrf1 signaling and ER stress crosstalk: Implication for proteasomal degradation and autophagy. Cell Mol. Life Sci. 2013, 70, 4681-4694. [CrossRef]

22. Hast, B.E.; Cloer, E.W.; Goldfarb, D.; Li, H.; Siesser, P.F.; Yan, F.; Walter, V.; Zheng, N.; Hayes, D.N.; Major, M.B. Cancer-derived mutations in KEAP1 impair NRF2 degradation but not ubiquitination. Cancer Res. 2014, 74, 808-817. [CrossRef]

23. Jaramillo, M.C.; Zhang, D.D. The emerging role of the Nrf2-Keap1 signaling pathway in cancer. Genes Dev. 2013, 27, 2179-2191. [CrossRef]

24. Bai, X.; Chen, Y.; Hou, X.; Huang, M.; Jin, J. Emerging role of NRF2 in chemoresistance by regulating drug-metabolizing enzymes and efflux transporters. Drug Metab. Rev. 2016, 48, 541-567. [CrossRef]

25. Basak, P.; Sadhukhan, P.; Sarkar, P.; Sil, P.C. Perspectives of the Nrf-2 signaling pathway in cancer progression and therapy. Toxicol. Rep. 2017, 4, 306-318. [CrossRef]

26. Menegon, S.; Columbano, A.; Giordano, S. The Dual Roles of NRF2 in Cancer. Trends Mol. Med. 2016, 22, 578-593. [CrossRef]

27. Xiang, M.; Namani, A.; Wu, S.; Wang, X. Nrf2: Bane or blessing in cancer? J. Cancer Res. Clin. Oncol. 2014, 140, 1251-1259. [CrossRef]

28. Sporn, M.B.; Liby, K.T. NRF2 and cancer: The good, the bad and the importance of context. Nat. Rev. Cancer 2012, 12, 564-571. [CrossRef]

29. Zhao, J. Cancer stem cells and chemoresistance: The smartest survives the raid. Pharmacol. Ther. 2016, 160, 145-158. [CrossRef]

30. Satoh, H.; Moriguchi, T.; Saigusa, D.; Baird, L.; Yu, L.; Rokutan, H.; Igarashi, K.; Ebina, M.; Shibata, T.; Yamamoto, M. NRF2 Intensifies Host Defense Systems to Prevent Lung Carcinogenesis, but After Tumor Initiation Accelerates Malignant Cell Growth. Cancer Res. 2016, 76, 3088-3096. [CrossRef]

31. Kansanen, E.; Kuosmanen, S.M.; Leinonen, H.; Levonen, A.L. The Keap1-Nrf2 pathway: Mechanisms of activation and dysregulation in cancer. Redox Biol. 2013, 1, 45-49. [CrossRef] [PubMed]

32. Taguchi, K.; Yamamoto, M. The KEAP1-NRF2 System in Cancer. Front. Oncol. 2017, 7, 85. [CrossRef] [PubMed]

33. Shibata, T.; Ohta, T.; Tong, K.I.; Kokubu, A.; Odogawa, R.; Tsuta, K.; Asamura, H.; Yamamoto, M.; Hirohashi, S. Cancer related mutations in NRF2 impair its recognition by Keap1-Cul3 E3 ligase and promote malignancy. Proc. Natl. Acad. Sci. USA 2008, 105, 13568-13573. [CrossRef] [PubMed]

34. Zavattari, P.; Perra, A.; Menegon, S.; Kowalik, M.A.; Petrelli, A.; Angioni, M.M.; Follenzi, A.; Quagliata, L.; Ledda-Columbano, G.M.; Terracciano, L.; et al. Nrf2, but not beta-catenin, mutation represents an early event in rat hepatocarcinogenesis. Hepatology 2015, 62, 851-862. [CrossRef] [PubMed] 
35. Hanada, N.; Takahata, T.; Zhou, Q.; Ye, X.; Sun, R.; Itoh, J.; Ishiguro, A.; Kijima, H.; Mimura, J.; Itoh, K.; et al. Methylation of the KEAP1 gene promoter region in human colorectal cancer. BMC Cancer 2012, 12, 66. [CrossRef] [PubMed]

36. Fabrizio, F.P.; Costantini, M.; Copetti, M.; la Torre, A.; Sparaneo, A.; Fontana, A.; Poeta, L.; Gallucci, M.; Sentinelli, S.; Graziano, P.; et al. Keap1/Nrf2 pathway in kidney cancer: Frequent methylation of KEAP1 gene promoter in clear renal cell carcinoma. Oncotarget 2017, 8, 11187-11198. [CrossRef]

37. Jung, B.J.; Yoo, H.S.; Shin, S.; Park, Y.J.; Jeon, S.M. Dysregulation of NRF2 in Cancer: From Molecular Mechanisms to Therapeutic Opportunities. Biomol. Ther. 2018, 26, 57-68. [CrossRef]

38. Kinch, L.; Grishin, N.V.; Brugarolas, J. Succination of Keap1 and activation of Nrf2-dependent antioxidant pathways in FH-deficient papillary renal cell carcinoma type 2. Cancer Cell 2011, 20, 418-420. [CrossRef]

39. Adam, J.; Hatipoglu, E.; O’Flaherty, L.; Ternette, N.; Sahgal, N.; Lockstone, H.; Baban, D.; Nye, E.; Stamp, G.W.; Wolhuter, K.; et al. Renal cyst formation in Fh1-deficient mice is independent of the Hif/Phd pathway: Roles for fumarate in KEAP1 succination and Nrf2 signaling. Cancer Cell 2011, 20, 524-537. [CrossRef]

40. Deshmukh, P.; Unni, S.; Krishnappa, G.; Padmanabhan, B. The Keap1-Nrf2 pathway: Promising therapeutic target to counteract ROS-mediated damage in cancers and neurodegenerative diseases. Biophys. Rev. 2017, 9, 41-56. [CrossRef]

41. Kageyama, S.; Saito, T.; Obata, M.; Koide, R.H.; Ichimura, Y.; Komatsu, M. Negative regulation of the Keap1-Nrf2 pathway by a p62/Sqstm1 splicing variant. Mol. Cell. Biol. 2018, 38, e00642-17. [CrossRef] [PubMed]

42. Ma, Q.; He, X. Molecular basis of electrophilic and oxidative defense: Promises and perils of Nrf2. Pharmacol. Rev. 2012, 64, 1055-1081. [CrossRef] [PubMed]

43. Karihtala, P.; Porvari, K.; Soini, Y.; Haapasaari, K.M. Redox Regulating Enzymes and Connected MicroRNA Regulators Have Prognostic Value in Classical Hodgkin Lymphomas. Oxid. Med. Cell Longev. 2017, 2017, 2696071. [CrossRef] [PubMed]

44. Fan, Z.; Wirth, A.K.; Chen, D.; Wruck, C.J.; Rauh, M.; Buchfelder, M.; Savaskan, N. Nrf2-Keap1 pathway promotes cell proliferation and diminishes ferroptosis. Oncogenesis 2017, 6, e371. [CrossRef]

45. Zhang, M.; Zhang, C.; Zhang, L.; Yang, Q.; Zhou, S.; Wen, Q.; Wang, J. Nrf2 is a potential prognostic marker and promotes proliferation and invasion in human hepatocellular carcinoma. BMC Cancer 2015, 15, 531. [CrossRef]

46. Pan, H.; Wang, H.; Zhu, L.; Mao, L.; Qiao, L.; Su, X. The role of Nrf2 in migration and invasion of human glioma cell U251. World Neurosurg. 2013, 80, 363-370. [CrossRef]

47. Niture, S.K.; Jaiswal, A.K. Nrf2 protein up-regulates antiapoptotic protein Bcl-2 and prevents cellular apoptosis. J. Biol. Chem. 2012, 287, 9873-9886. [CrossRef]

48. Ma, J.Q.; Tuersun, H.; Jiao, S.J.; Zheng, J.H.; Xiao, J.B.; Hasim, A. Functional Role of NRF2 in Cervical Carcinogenesis. PLoS ONE 2015, 10, e0133876. [CrossRef]

49. Gorrini, C.; Baniasadi, P.S.; Harris, I.S.; Silvester, J.; Inoue, S.; Snow, B.; Joshi, P.A.; Wakeham, A.; Molyneux, S.D.; Martin, B.; et al. BRCA1 interacts with Nrf2 to regulate antioxidant signaling and cell survival. J. Exp. Med. 2013, 210, 1529-1544. [CrossRef]

50. Banning, A.; Brigelius-Flohe, R. NF-kappaB, Nrf2, and HO-1 interplay in redox-regulated VCAM-1 expression. Antioxid. Redox Signal. 2005, 7, 889-899. [CrossRef]

51. Kim, W.D.; Kim, Y.W.; Cho, I.J.; Lee, C.H.; Kim, S.G. E-cadherin inhibits nuclear accumulation of Nrf2: Implications for chemoresistance of cancer cells. J. Cell Sci. 2012, 125, 1284-1295. [CrossRef] [PubMed]

52. Zhou, W.; Mo, X.; Cui, W.; Zhang, Z.; Li, D.; Li, L.; Xu, L.; Yao, H.; Gao, J. Nrf2 inhibits epithelial-mesenchymal transition by suppressing snail expression during pulmonary fibrosis. Sci. Rep. 2016, 6, 38646. [CrossRef] [PubMed]

53. Kozakowska, M.; Dobrowolska-Glazar, B.; Okon, K.; Jozkowicz, A.; Dobrowolski, Z.; Dulak, J. Preliminary Analysis of the Expression of Selected Proangiogenic and Antioxidant Genes and MicroRNAs in Patients with Non-Muscle-Invasive Bladder Cancer. J. Clin. Med. 2016, 5, 29. [CrossRef] [PubMed]

54. Shanmugam, G.; Narasimhan, M.; Sakthivel, R.; Kumar, R.R.; Davidson, C.; Palaniappan, S.; Claycomb, W.W.; Hoidal, J.R.; Darley-Usmar, V.M.; Rajasekaran, N.S. A biphasic effect of TNF-alpha in regulation of the Keap1/Nrf2 pathway in cardiomyocytes. Redox Biol. 2016, 9, 77-89. [CrossRef] [PubMed] 
55. Potteti, H.R.; Tamatam, C.R.; Marreddy, R.; Reddy, N.M.; Noel, S.; Rabb, H.; Reddy, S.P. Nrf2-AKT interactions regulate heme oxygenase 1 expression in kidney epithelia during hypoxia and hypoxia-reoxygenation. Am. J. Physiol. Renal Physiol. 2016, 311, F1025-F1034. [CrossRef] [PubMed]

56. Mani, M.; Khaghani, S.; Gol Mohammadi, T.; Zamani, Z.; Azadmanesh, K.; Meshkani, R.; Pasalar, P.; Mostafavi, E. Activation of Nrf2-Antioxidant Response Element Mediated Glutamate Cysteine Ligase Expression in Hepatoma Cell line by Homocysteine. Hepat. Mon. 2013, 13, e8394. [CrossRef]

57. Tertil, M.; Golda, S.; Skrzypek, K.; Florczyk, U.; Weglarczyk, K.; Kotlinowski, J.; Maleszewska, M.; Czauderna, S.; Pichon, C.; Kieda, C.; et al. Nrf2-heme oxygenase-1 axis in mucoepidermoid carcinoma of the lung: Antitumoral effects associated with down-regulation of matrix metalloproteinases. Free Radic. Biol. Med. 2015, 89, 147-157. [CrossRef]

58. Kitamura, H.; Onodera, Y.; Murakami, S.; Suzuki, T.; Motohashi, H. IL-11 contribution to tumorigenesis in an NRF2 addiction cancer model. Oncogene 2017, 36, 6315-6324. [CrossRef]

59. Maj, T.; Wang, W.; Crespo, J.; Zhang, H.; Wang, W.; Wei, S.; Zhao, L.; Vatan, L.; Shao, I.; Szeliga, W.; et al. Oxidative stress controls regulatory $\mathrm{T}$ cell apoptosis and suppressor activity and PD-L1-blockade resistance in tumor. Nat. Immunol. 2017, 18, 1332-1341. [CrossRef]

60. Li, C.; Wu, H.; Wang, S.; Zhu, J. Expression and correlation of NRF2, KEAP1, NQO-1 and HO-1 in advanced squamous cell carcinoma of the larynx and their association with clinicopathologic features. Mol. Med. Rep. 2016, 14, 5171-5179. [CrossRef]

61. Kim, H.J.; Zheng, M.; Kim, S.K.; Cho, J.J.; Shin, C.H.; Joe, Y.; Chung, H.T. CO/HO-1 Induces NQO-1 Expression via Nrf2 Activation. Immune Netw. 2011, 11, 376-382. [CrossRef] [PubMed]

62. Ji, L.; Li, H.; Gao, P.; Shang, G.; Zhang, D.D.; Zhang, N.; Jiang, T. Nrf2 pathway regulates multidrug-resistance-associated protein 1 in small cell lung cancer. PLoS ONE 2013, 8, e63404. [CrossRef] [PubMed]

63. Hong, Y.B.; Kang, H.J.; Kwon, S.Y.; Kim, H.J.; Kwon, K.Y.; Cho, C.H.; Lee, J.M.; Kallakury, B.V.; Bae, I. Nuclear factor (erythroid-derived 2)-like 2 regulates drug resistance in pancreatic cancer cells. Pancreas 2010, 39, 463-472. [CrossRef] [PubMed]

64. Kang, H.J.; Yi, Y.W.; Hong, Y.B.; Kim, H.J.; Jang, Y.J.; Seong, Y.S.; Bae, I. HER2 confers drug resistance of human breast cancer cells through activation of NRF2 by direct interaction. Sci. Rep. 2014, 4, 7201. [CrossRef] [PubMed]

65. Bao, L.; Wu, J.; Dodson, M.; de la Vega, E.M.R.; Ning, Y.; Zhang, Z.; Yao, M.; Zhang, D.D.; Xu, C.; Yi, X. $\mathrm{ABCF} 2$, an Nrf2 target gene, contributes to cisplatin resistance in ovarian cancer cells. Mol. Carcinog. 2017, 56, 1543-1553. [CrossRef]

66. Syu, J.P.; Chi, J.T.; Kung, H.N. Nrf2 is the key to chemotherapy resistance in MCF7 breast cancer cells under hypoxia. Oncotarget 2016, 7, 14659-14672. [CrossRef]

67. Ryoo, I.G.; Kim, G.; Choi, B.H.; Lee, S.H.; Kwak, M.K. Involvement of NRF2 Signaling in Doxorubicin Resistance of Cancer Stem Cell-Enriched Colonospheres. Biomol. Ther. 2016, 24, 482-488. [CrossRef]

68. Mitsuishi, Y.; Taguchi, K.; Kawatani, Y.; Shibata, T.; Nukiwa, T.; Aburatani, H.; Yamamoto, M.; Motohashi, H. $\mathrm{Nrf} 2$ redirects glucose and glutamine into anabolic pathways in metabolic reprogramming. Cancer Cell 2012, 22, 66-79. [CrossRef]

69. Hayes, J.D.; Dinkova-Kostova, A.T. The Nrf2 regulatory network provides an interface between redox and intermediary metabolism. Trends Biochem. Sci. 2014, 39, 199-218. [CrossRef]

70. Hayes, J.D.; Ashford, M.L. Nrf2 orchestrates fuel partitioning for cell proliferation. Cell Metab. 2012, 16, 139-141. [CrossRef]

71. DeNicola, G.M.; Chen, P.H.; Mullarky, E.; Sudderth, J.A.; Hu, Z.; Wu, D.; Tang, H.; Xie, Y.; Asara, J.M.; Huffman, K.E.; et al. NRF2 regulates serine biosynthesis in non-small cell lung cancer. Nat. Genet. 2015, 47, 1475-1481. [CrossRef] [PubMed]

72. Namani, A.; Cui, Q.Q.; Wu, Y.; Wang, H.; Wang, X.J.; Tang, X. NRF2-regulated metabolic gene signature as a prognostic biomarker in non-small cell lung cancer. Oncotarget 2017, 8, 69847-69862. [CrossRef] [PubMed]

73. Xu, I.M.; Lai, R.K.; Lin, S.H.; Tse, A.P.; Chiu, D.K.; Koh, H.Y.; Law, C.T.; Wong, C.M.; Cai, Z.; Wong, C.C.; et al. Transketolase counteracts oxidative stress to drive cancer development. Proc. Natl. Acad. Sci. USA 2016, 113, E725-E734. [CrossRef] [PubMed]

74. Namani, A.; Li, Y.; Wang, X.J.; Tang, X. Modulation of NRF2 signaling pathway by nuclear receptors: Implications for cancer. Biochim. Biophys. Acta 2014, 1843, 1875-1885. [CrossRef] [PubMed] 
75. Ge, W.; Zhao, K.; Wang, X.; Li, H.; Yu, M.; He, M.; Xue, X.; Zhu, Y.; Zhang, C.; Cheng, Y.; et al. iASPP Is an Antioxidative Factor and Drives Cancer Growth and Drug Resistance by Competing with Nrf2 for Keap1 Binding. Cancer Cell 2017, 32, 561-573. [CrossRef] [PubMed]

76. Cullinan, S.B.; Zhang, D.; Hannink, M.; Arvisais, E.; Kaufman, R.J.; Diehl, J.A. Nrf2 is a direct PERK substrate and effector of PERK-dependent cell survival. Mol. Cell. Biol. 2003, 23, 7198-7209. [CrossRef] [PubMed]

77. Tung, M.C.; Lin, P.L.; Wang, Y.C.; He, T.Y.; Lee, M.C.; Yeh, S.D.; Chen, C.Y.; Lee, H. Mutant p53 confers chemoresistance in non-small cell lung cancer by upregulating Nrf2. Oncotarget 2015, 6, 41692-41705. [CrossRef]

78. Braicu, C.; Pileczki, V.; Irimie, A.; Berindan-Neagoe, I. p53siRNA therapy reduces cell proliferation, migration and induces apoptosis in triple negative breast cancer cells. Mol. Cell. Biochem. 2013, 381, 61-68. [CrossRef]

79. Chen, X.; Guan, H.; Liu, X.D.; Xie, D.F.; Wang, Y.; Ma, T.; Huang, B.; Zhou, P.K. p53 positively regulates the expression of cancer stem cell marker CD133 in HCT116 colon cancer cells. Oncol. Lett. 2018, 16, 431-438. [CrossRef]

80. Liu, X.; Lin, X.J.; Wang, C.P.; Yan, K.K.; Zhao, L.Y.; An, W.X.; Liu, X.D. Association between smoking and p53 mutation in lung cancer: A meta-analysis. Clin. Oncol. 2014, 26, 18-24. [CrossRef]

81. Hayden, A.; Douglas, J.; Sommerlad, M.; Andrews, L.; Gould, K.; Hussain, S.; Thomas, G.J.; Packham, G.; Crabb, S.J. The Nrf2 transcription factor contributes to resistance to cisplatin in bladder cancer. Urol. Oncol. 2014, 32, 806-814. [CrossRef] [PubMed]

82. Wu, T.; Harder, B.G.; Wong, P.K.; Lang, J.E.; Zhang, D.D. Oxidative stress, mammospheres and Nrf2-new implication for breast cancer therapy? Mol. Carcinog. 2015, 54, 1494-1502. [CrossRef] [PubMed]

83. Onodera, Y.; Motohashi, H.; Takagi, K.; Miki, Y.; Shibahara, Y.; Watanabe, M.; Ishida, T.; Hirakawa, H.; Sasano, H.; Yamamoto, M.; et al. NRF2 immunolocalization in human breast cancer patients as a prognostic factor. Endocr. Relat. Cancer 2014, 21, 241-252. [CrossRef] [PubMed]

84. Khatri, R.; Shah, P.; Guha, R.; Rassool, F.V.; Tomkinson, A.E.; Brodie, A.; Jaiswal, A.K. Aromatase Inhibitor-Mediated Downregulation of INrf2 (Keap1) Leads to Increased Nrf2 and Resistance in Breast Cancer. Mol. Cancer Ther. 2015, 14, 1728-1737. [CrossRef]

85. Choi, B.H.; Ryoo, I.G.; Kang, H.C.; Kwak, M.K. The sensitivity of cancer cells to pheophorbide a-based photodynamic therapy is enhanced by Nrf2 silencing. PLoS ONE 2014, 9, e107158. [CrossRef]

86. Zhang, C.; Wang, H.J.; Bao, Q.C.; Wang, L.; Guo, T.K.; Chen, W.L.; Xu, L.L.; Zhou, H.S.; Bian, J.L.; Yang, Y.R.; et al. NRF2 promotes breast cancer cell proliferation and metastasis by increasing RhoA/ROCK pathway signal transduction. Oncotarget 2016, 7, 73593-73606. [CrossRef]

87. Zhang, H.S.; Du, G.Y.; Zhang, Z.G.; Zhou, Z.; Sun, H.L.; Yu, X.Y.; Shi, Y.T.; Xiong, D.N.; Li, H.; Huang, Y.H. NRF2 facilitates breast cancer cell growth via HIF1a-mediated metabolic reprogramming. Int. J. Biochem. Cell Biol. 2018, 95, 85-92. [CrossRef]

88. Jia, Y.; Chen, J.; Zhu, H.; Jia, Z.H.; Cui, M.H. Aberrantly elevated redox sensing factor Nrf2 promotes cancer stem cell survival via enhanced transcriptional regulation of ABCG2 and Bcl-2/Bmi-1 genes. Oncol. Rep. 2015, 34, 2296-2304. [CrossRef]

89. Shukla, K.; Sonowal, H.; Saxena, A.; Ramana, K.V.; Srivastava, S.K. Aldose reductase inhibitor, fidarestat regulates mitochondrial biogenesis via Nrf2/HO-1/AMPK pathway in colon cancer cells. Cancer Lett. 2017, 411, 57-63. [CrossRef]

90. Kang, K.A.; Piao, M.J.; Kim, K.C.; Kang, H.K.; Chang, W.Y.; Park, I.C.; Keum, Y.S.; Surh, Y.J.; Hyun, J.W. Epigenetic modification of Nrf2 in 5-fluorouracil-resistant colon cancer cells: Involvement of TET-dependent DNA demethylation. Cell Death Dis. 2014, 5, e1183. [CrossRef]

91. Chian, S.; Li, Y.Y.; Wang, X.J.; Tang, X.W. Luteolin sensitizes two oxaliplatin-resistant colorectal cancer cell lines to chemotherapeutic drugs via inhibition of the Nrf2 pathway. Asian Pac. J. Cancer Prev. 2014, 15, 2911-2916. [CrossRef] [PubMed]

92. Jeddi, F.; Soozangar, N.; Sadeghi, M.R.; Somi, M.H.; Shirmohamadi, M.; Eftekhar-Sadat, A.T.; Samadi, N. Nrf2 overexpression is associated with P-glycoprotein upregulation in gastric cancer. Biomed. Pharmacother. 2018, 97, 286-292. [CrossRef] [PubMed]

93. Wang, Z.; Ma, L.; Zhang, X.M.; Zhou, Z.X. Risk of lymph node metastases from early gastric cancer in relation to depth of invasion: Experience in a single institution. Asian Pac. J. Cancer Prev. 2014, 15, 5371-5375. [CrossRef] [PubMed] 
94. Kawasaki, Y.; Ishigami, S.; Arigami, T.; Uenosono, Y.; Yanagita, S.; Uchikado, Y.; Kita, Y.; Nishizono, Y.; Okumura, H.; Nakajo, A.; et al. Clinicopathological significance of nuclear factor (erythroid-2)-related factor 2 (Nrf2) expression in gastric cancer. BMC Cancer 2015, 15, 5. [CrossRef]

95. Cong, Z.X.; Wang, H.D.; Zhou, Y.; Wang, J.W.; Pan, H.; Zhang, D.D.; Zhang, L.; Zhu, L. Temozolomide and irradiation combined treatment-induced Nrf2 activation increases chemoradiation sensitivity in human glioblastoma cells. J. Neurooncol. 2014, 116, 41-48. [CrossRef]

96. Ouyang, W.C.; Liao, Y.W.; Chen, P.N.; Lu, K.H.; Yu, C.C.; Hsieh, P.L. Hinokitiol suppresses cancer stemness and oncogenicity in glioma stem cells by Nrf2 regulation. Cancer Chemother. Pharmacol. 2017, 80, 411-419. [CrossRef]

97. Shi, L.; Wu, L.; Chen, Z.; Yang, J.; Chen, X.; Yu, F.; Zheng, F.; Lin, X. MiR-141 Activates Nrf2-Dependent Antioxidant Pathway via Down-Regulating the Expression of Keap1 Conferring the Resistance of Hepatocellular Carcinoma Cells to 5-Fluorouracil. Cell. Physiol. Biochem. Int. J. Exp. Cell. Physiol. Biochem. Pharmacol. 2015, 35, 2333-2348. [CrossRef]

98. Lim, J.; Lee, S.H.; Cho, S.; Lee, I.S.; Kang, B.Y.; Choi, H.J. 4-methoxychalcone enhances cisplatin-induced oxidative stress and cytotoxicity by inhibiting the Nrf2/ARE-mediated defense mechanism in A549 lung cancer cells. Mol. Cells 2013, 36, 340-346. [CrossRef]

99. Sun, Y.; Abdul Aziz, A.; Bowles, K.; Rushworth, S. High NRF2 expression controls endoplasmic reticulum stress induced apoptosis in multiple myeloma. Cancer Lett. 2018, 412, 37-45. [CrossRef]

100. Todoric, J.; Antonucci, L.; Di Caro, G.; Li, N.; Wu, X.; Lytle, N.K.; Dhar, D.; Banerjee, S.; Fagman, J.B.; Browne, C.D.; et al. Stress-Activated NRF2-MDM2 Cascade Controls Neoplastic Progression in Pancreas. Cancer Cell 2017, 32, 824-839.e8. [CrossRef]

101. Arlt, A.; Sebens, S.; Krebs, S.; Geismann, C.; Grossmann, M.; Kruse, M.L.; Schreiber, S.; Schafer, H. Inhibition of the Nrf2 transcription factor by the alkaloid trigonelline renders pancreatic cancer cells more susceptible to apoptosis through decreased proteasomal gene expression and proteasome activity. Oncogene 2013, 32, 4825-4835. [CrossRef] [PubMed]

102. Genrich, G.; Kruppa, M.; Lenk, L.; Helm, O.; Broich, A.; Freitag-Wolf, S.; Rocken, C.; Sipos, B.; Schafer, H.; Sebens, S. The anti-oxidative transcription factor Nuclear factor E2 related factor-2 (Nrf2) counteracts TGF-beta1 mediated growth inhibition of pancreatic ductal epithelial cells -Nrf2 as determinant of pro-tumorigenic functions of TGF-beta1. BMC Cancer 2016, 16, 155. [CrossRef] [PubMed]

103. Khor, T.O.; Fuentes, F.; Shu, L.; Paredes-Gonzalez, X.; Yang, A.Y.; Liu, Y.; Smiraglia, D.J.; Yegnasubramanian, S.; Nelson, W.G.; Kong, A.N. Epigenetic DNA methylation of antioxidative stress regulator NRF2 in human prostate cancer. Cancer Prev. Res. 2014, 7, 1186-1197. [CrossRef] [PubMed]

104. Liu, M.; Yao, X.D.; Li, W.; Geng, J.; Yan, Y.; Che, J.P.; Xu, Y.F.; Zheng, J.H. Nrf2 sensitizes prostate cancer cells to radiation via decreasing basal ROS levels. Biofactors 2015, 41, 52-57. [CrossRef] [PubMed]

105. Tian, S.; Yong, M.; Zhu, J.; Zhang, L.; Pan, L.; Chen, Q.; Li, K.T.; Kong, Y.H.; Jiang, Y.; Yu, T.H.; et al. Enhancement of the Effect of Methyl Pyropheophorbide-a-Mediated Photodynamic Therapy was Achieved by Increasing ROS through Inhibition of Nrf2-HO-1 or Nrf2-ABCG2 Signaling. Anticancer Agents Med. Chem. 2017, 17, 1824-1836. [CrossRef]

106. Cheung, K.L.; Lee, J.H.; Shu, L.; Kim, J.H.; Sacks, D.B.; Kong, A.N. The Ras GTPase-activating-like protein IQGAP1 mediates Nrf2 protein activation via the mitogen-activated protein kinase/extracellular signal-regulated kinase (ERK) kinase (MEK)-ERK pathway. J. Biol. Chem. 2013, 288, 22378-22386. [CrossRef]

107. Zhao, H.Y.; Han, Y.; Wang, J.; Yang, L.H.; Zheng, X.Y.; Du, J.; Wu, G.P.; Wang, E.H. IQ-domain GTPase-activating protein 1 promotes the malignant phenotype of invasive ductal breast carcinoma via canonical Wnt pathway. Tumour Biol. 2017, 39, 1010428317705769. [CrossRef]

108. Diao, B.; Liu, Y.; Zhang, Y.; Yu, J.; Xie, J.; Xu, G.Z. IQGAP1siRNA inhibits proliferation and metastasis of U251 and U373 glioma cell lines. Mol. Med. Rep. 2017, 15, 2074-2082. [CrossRef]

109. Huang, L.; Xu, S.; Hu, D.; Lu, W.; Xie, X.; Cheng, X. IQGAP1 Is Involved in Enhanced Aggressive Behavior of Epithelial Ovarian Cancer Stem Cell-Like Cells During Differentiation. Int. J. Gynecol. Cancer 2015, 25, 559-565. [CrossRef]

110. Hoesel, B.; Schmid, J.A. The complexity of NF-kappaB signaling in inflammation and cancer. Mol. Cancer 2013, 12, 86. [CrossRef]

111. Xia, Y.; Shen, S.; Verma, I.M. NF-kappaB, an active player in human cancers. Cancer Immunol. Res. 2014, 2, 823-830. [CrossRef] [PubMed] 
112. Bellezza, I.; Mierla, A.L.; Minelli, A. Nrf2 and NF-kappaB and Their Concerted Modulation in Cancer Pathogenesis and Progression. Cancers 2010, 2, 483-497. [CrossRef] [PubMed]

113. Ahmed, S.M.; Luo, L.; Namani, A.; Wang, X.J.; Tang, X. Nrf2 signaling pathway: Pivotal roles in inflammation. Biochim. Biophys. Acta 2017, 1863, 585-597. [CrossRef] [PubMed]

114. Lee, D.F.; Kuo, H.P.; Liu, M.; Chou, C.K.; Xia, W.; Du, Y.; Shen, J.; Chen, C.T.; Huo, L.; Hsu, M.C.; et al. KEAP1 E3 ligase-mediated downregulation of NF-kappaB signaling by targeting IKKbeta. Mol. Cell 2009, 36, 131-140. [CrossRef] [PubMed]

115. Liu, G.H.; Qu, J.; Shen, X. NF-kappaB/p65 antagonizes Nrf2-ARE pathway by depriving CBP from Nrf2 and facilitating recruitment of HDAC3 to MafK. Biochim. Biophys. Acta 2008, 1783, 713-727. [CrossRef] [PubMed]

116. Hwang, Y.J.; Lee, E.W.; Song, J.; Kim, H.R.; Jun, Y.C.; Hwang, K.A. MafK positively regulates NF-kappaB activity by enhancing CBP-mediated p65 acetylation. Sci. Rep. 2013, 3, 3242. [CrossRef]

117. Osaki, M.; Oshimura, M.; Ito, H. PI3K-Akt pathway: Its functions and alterations in human cancer. Apoptosis 2004, 9, 667-676. [CrossRef]

118. Chang, F.; Lee, J.T.; Navolanic, P.M.; Steelman, L.S.; Shelton, J.G.; Blalock, W.L.; Franklin, R.A.; McCubrey, J.A. Involvement of PI3K/Akt pathway in cell cycle progression, apoptosis, and neoplastic transformation: A target for cancer chemotherapy. Leukemia 2003, 17, 590-603. [CrossRef]

119. Liu, D.; Zhang, Y.; Wei, Y.; Liu, G.; Liu, Y.; Gao, Q.; Zou, L.; Zeng, W.; Zhang, N. Activation of AKT pathway by Nrf2/PDGFA feedback loop contributes to HCC progression. Oncotarget 2016, 7, 65389-65402. [CrossRef]

120. Fan, H.; Paiboonrungruan, C.; Zhang, X.; Prigge, J.R.; Schmidt, E.E.; Sun, Z.; Chen, X. Nrf2 regulates cellular behaviors and Notch signaling in oral squamous cell carcinoma cells. Biochem. Biophys. Res. Commun. 2017, 493, 833-839. [CrossRef]

121. Ma, L.; Liu, J.; Zhang, X.; Qi, J.; Yu, W.; Gu, Y. p38 MAPK-dependent Nrf2 induction enhances the resistance of glioma cells against TMZ. Med. Oncol. 2015, 32, 69. [CrossRef] [PubMed]

122. Wardyn, J.D.; Ponsford, A.H.; Sanderson, C.M. Dissecting molecular cross-talk between Nrf2 and NF-kappaB response pathways. Biochem. Soc. Trans. 2015, 43, 621-626. [CrossRef] [PubMed]

123. Jiang, T.; Tian, F.; Zheng, H.; Whitman, S.A.; Lin, Y.; Zhang, Z.; Zhang, N.; Zhang, D.D. Nrf2 suppresses lupus nephritis through inhibition of oxidative injury and the NF-kappaB-mediated inflammatory response. Kidney Int. 2014, 85, 333-343. [CrossRef] [PubMed]

124. Cuadrado, A.; Martin-Moldes, Z.; Ye, J.; Lastres-Becker, I. Transcription factors NRF2 and NF-kappaB are coordinated effectors of the Rho family, GTP-binding protein RAC1 during inflammation. J. Biol. Chem. 2014, 289, 15244-15258. [CrossRef] [PubMed]

125. Koundouros, N.; Poulogiannis, G. Phosphoinositide 3-Kinase/Akt Signaling and Redox Metabolism in Cancer. Front. Oncol. 2018, 8, 160. [CrossRef] [PubMed]

126. Best, S.A.; De Souza, D.P.; Kersbergen, A.; Policheni, A.N.; Dayalan, S.; Tull, D.; Rathi, V.; Gray, D.H.; Ritchie, M.E.; McConville, M.J.; et al. Synergy between the KEAP1/NRF2 and PI3K Pathways Drives Non-Small-Cell Lung Cancer with an Altered Immune Microenvironment. Cell Metab. 2018, 27. [CrossRef] [PubMed]

127. Rada, P.; Rojo, A.I.; Offergeld, A.; Feng, G.J.; Velasco-Martin, J.P.; Gonzalez-Sancho, J.M.; Valverde, A.M.; Dale, T.; Regadera, J.; Cuadrado, A. WNT-3A regulates an Axin1/NRF2 complex that regulates antioxidant metabolism in hepatocytes. Antioxid. Redox Signal. 2015, 22, 555-571. [CrossRef]

128. DeNicola, G.M.; Karreth, F.A.; Humpton, T.J.; Gopinathan, A.; Wei, C.; Frese, K.; Mangal, D.; Yu, K.H.; Yeo, C.J.; Calhoun, E.S.; et al. Oncogene-induced Nrf2 transcription promotes ROS detoxification and tumorigenesis. Nature 2011, 475, 106-109. [CrossRef]

129. Komatsu, M.; Kurokawa, H.; Waguri, S.; Taguchi, K.; Kobayashi, A.; Ichimura, Y.; Sou, Y.S.; Ueno, I.; Sakamoto, A.; Tong, K.I.; et al. The selective autophagy substrate p62 activates the stress responsive transcription factor Nrf2 through inactivation of Keap1. Nat. Cell Biol. 2010, 12, 213-223. [CrossRef]

130. Liu, Q.; Lei, Z.; Huang, A.; Wu, Q.; Xie, S.; Awais, I.; Dai, M.; Wang, X.; Yuan, Z. Toxic metabolites, MAPK and Nrf2/Keap1 signaling pathways involved in oxidative toxicity in mice liver after chronic exposure to Mequindox. Sci. Rep. 2017, 7, 41854. [CrossRef]

131. Cardinal-Fernandez, P.; Ferruelo, A.; Esteban, A.; Lorente, J.A. Characteristics of microRNAs and their potential relevance for the diagnosis and therapy of the acute respiratory distress syndrome: From bench to bedside. Transl. Res. 2016, 169, 102-111. [CrossRef] [PubMed] 
132. Hashimoto, Y.; Akiyama, Y.; Yuasa, Y. Multiple-to-multiple relationships between microRNAs and target genes in gastric cancer. PLoS ONE 2013, 8, e62589. [CrossRef] [PubMed]

133. Chen, C.Z. MicroRNAs as oncogenes and tumor suppressors. N. Engl. J. Med. 2005, 353, $1768-1771$. [CrossRef] [PubMed]

134. Redis, R.S.; Berindan-Neagoe, I.; Pop, V.I.; Calin, G.A. Non-coding RNAs as theranostics in human cancers. J. Cell. Biochem. 2012, 113, 1451-1459. [CrossRef] [PubMed]

135. Braicu, C.; Catana, C.; Calin, G.A.; Berindan-Neagoe, I. NCRNA combined therapy as future treatment option for cancer. Curr. Pharm. Des. 2014, 20, 6565-6574. [CrossRef]

136. Akdemir, B.; Nakajima, Y.; Inazawa, J.; Inoue, J. miR-432 Induces NRF2 Stabilization by Directly Targeting KEAP1. Mol. Cancer Res. 2017, 15, 1570-1578. [CrossRef]

137. Chen, C.; Jiang, X.; Gu, S.; Zhang, Z. MicroRNA-155 regulates arsenite-induced malignant transformation by targeting Nrf2-mediated oxidative damage in human bronchial epithelial cells. Toxicol. Lett. 2017, 278, 38-47. [CrossRef]

138. Sun, X.; Liu, D.; Xue, Y.; Hu, X. Enforced miR-144-3p Expression as a Non-Invasive Biomarker for the Acute Myeloid Leukemia Patients Mainly by Targeting NRF2. Clin. Lab. 2017, 63, 679-687. [CrossRef]

139. Yang, M.; Yao, Y.; Eades, G.; Zhang, Y.; Zhou, Q. MiR-28 regulates Nrf2 expression through a Keap1-independent mechanism. Breast Cancer Res. Treat. 2011, 129, 983-991. [CrossRef]

140. Qu, J.; Zhang, L.; Li, L.; Su, Y. MiR-148b functions as a tumor suppressor by targeting endoplasmic reticulum metallo protease 1 in human endometrial cancer cells. Oncol. Res. 2018, 27, 81-88. [CrossRef]

141. Jung, K.A.; Lee, S.; Kwak, M.K. NFE2L2/NRF2 Activity Is Linked to Mitochondria and AMP-Activated Protein Kinase Signaling in Cancers through miR-181c/Mitochondria-Encoded Cytochrome c Oxidase Regulation. Antioxid. Redox Signal. 2017, 27, 945-961. [CrossRef] [PubMed]

142. Shah, N.M.; Rushworth, S.A.; Murray, M.Y.; Bowles, K.M.; MacEwan, D.J. Understanding the role of NRF2-regulated miRNAs in human malignancies. Oncotarget 2013, 4, 1130-1142. [CrossRef] [PubMed]

143. Zhang, C.; Shu, L.; Kong, A.N. MicroRNAs: New players in cancer prevention targeting Nrf2, oxidative stress and inflammatory pathways. Curr. Pharmacol. Rep. 2015, 1, 21-30. [CrossRef] [PubMed]

144. Marts, L.T.; Green, D.E.; Mills, S.T.; Murphy, T.; Sueblinvong, V. MiR-21-Mediated Suppression of Smad7 Induces TGFbeta1 and Can Be Inhibited by Activation of Nrf2 in Alcohol-Treated Lung Fibroblasts. Alcohol. Clin. Exp. Res. 2017, 41, 1875-1885. [CrossRef]

145. Ayers, D.; Baron, B.; Hunter, T. miRNA Influences in NRF2 Pathway Interactions within Cancer Models. J. Nucleic Acids 2015, 2015, 143636. [CrossRef]

146. Eades, G.; Yang, M.; Yao, Y.; Zhang, Y.; Zhou, Q. miR-200a regulates Nrf2 activation by targeting Keap1 mRNA in breast cancer cells. J. Boil. Chem. 2011, 286, 40725-40733. [CrossRef]

147. Liu, M.; Hu, C.; Xu, Q.; Chen, L.; Ma, K.; Xu, N.; Zhu, H. Methylseleninic acid activates Keap1/Nrf2 pathway via up-regulating miR-200a in human oesophageal squamous cell carcinoma cells. Biosci. Rep. 2015, 35. [CrossRef]

148. Liu, Q.L.; Zhang, J.; Liu, X.; Gao, J.Y. Role of growth hormone in maturation and activation of dendritic cells via miR-200a and the Keap1/Nrf2 pathway. Cell Prolif. 2015, 48, 573-581. [CrossRef]

149. Duru, N.; Gernapudi, R.; Zhang, Y.; Yao, Y.; Lo, P.K.; Wolfson, B.; Zhou, Q. NRF2/miR-140 signaling confers radioprotection to human lung fibroblasts. Cancer Lett. 2015, 369, 184-191. [CrossRef]

150. Shi, L.; Chen, Z.G.; Wu, L.L.; Zheng, J.J.; Yang, J.R.; Chen, X.F.; Chen, Z.Q.; Liu, C.L.; Chi, S.Y.; Zheng, J.Y.; et al. miR-340 reverses cisplatin resistance of hepatocellular carcinoma cell lines by targeting Nrf2-dependent antioxidant pathway. Asian Pac. J. Cancer Prev. 2014, 15, 10439-10444. [CrossRef]

151. Shah, N.M.; Zaitseva, L.; Bowles, K.M.; MacEwan, D.J.; Rushworth, S.A. NRF2-driven miR-125B1 and miR-29B1 transcriptional regulation controls a novel anti-apoptotic miRNA regulatory network for AML survival. Cell Death Differ. 2015, 22, 654-664. [CrossRef] [PubMed]

152. Kurinna, S.; Schafer, M.; Ostano, P.; Karouzakis, E.; Chiorino, G.; Bloch, W.; Bachmann, A.; Gay, S.; Garrod, D.; Lefort, K.; et al. A novel Nrf2-miR-29-desmocollin-2 axis regulates desmosome function in keratinocytes. Nat. Commun. 2014, 5, 5099. [CrossRef] [PubMed]

153. Aldea, M.; Craciun, L.; Tomuleasa, C.; Berindan-Neagoe, I.; Kacso, G.; Florian, I.S.; Crivii, C. Repositioning metformin in cancer: Genetics, drug targets, and new ways of delivery. Tumor Biol. 2014, 35, 5101-5110. [CrossRef] [PubMed] 
154. Do, M.T.; Kim, H.G.; Choi, J.H.; Jeong, H.G. Metformin induces microRNA-34a to downregulate the Sirt1/Pgc-1alpha/Nrf2 pathway, leading to increased susceptibility of wild-type p53 cancer cells to oxidative stress and therapeutic agents. Free Radic. Biol. Med. 2014, 74, 21-34. [CrossRef]

155. Khan, A.U.H.; Rathore, M.G.; Allende-Vega, N.; Vo, D.N.; Belkhala, S.; Orecchioni, S.; Talarico, G.; Bertolini, F.; Cartron, G.; Lecellier, C.H.; et al. Human Leukemic Cells performing Oxidative Phosphorylation (OXPHOS) Generate an Antioxidant Response Independently of Reactive Oxygen species (ROS) Production. EBioMedicine 2016, 3, 43-53. [CrossRef]

156. Rose, A.S.; Bradley, A.R.; Valasatava, Y.; Duarte, J.M.; Prlić, A.; Rose, P.W. Web-based molecular graphics for large complexes. In Proceedings of the ACM 21st International Conference on Web3D Technology (Web3D '16), Anaheim, CA, USA, 22-24 July 2016; pp. 185-186. [CrossRef]

157. Rose, A.S.; Hildebrand, P.W. NGL Viewer: A web application for molecular visualization. Nucl. Acids Res. 2015, 43, W576-W579. [CrossRef]

158. Yoshino, H.; Murakami, K.; Nawamaki, M.; Kashiwakura, I. Effects of Nrf2 knockdown on the properties of irradiated cell conditioned medium from A549 human lung cancer cells. Biomed. Rep. 2018, 8, 461-465. [CrossRef]

159. Tian, X.; Wang, F.; Luo, Y.; Ma, S.; Zhang, N.; Sun, Y.; You, C.; Tang, G.; Li, S.; Gong, Y.; et al. Protective Role of Nuclear Factor-Erythroid 2-Related Factor 2 against Radiation-Induced Lung Injury and Inflammation. Front. Oncol. 2018, 8, 542. [CrossRef]

160. Krause, M.; Dubrovska, A.; Linge, A.; Baumann, M. Cancer stem cells: Radioresistance, prediction of radiotherapy outcome and specific targets for combined treatments. Adv. Drug Deliv. Rev. 2017, 109, 63-73. [CrossRef]

161. McDonald, J.T.; Kim, K.; Norris, A.J.; Vlashi, E.; Phillips, T.M.; Lagadec, C.; Della Donna, L.; Ratikan, J.; Szelag, H.; Hlatky, L.; et al. Ionizing radiation activates the Nrf2 antioxidant response. Cancer Res. 2010, 70, 8886-8895. [CrossRef]

162. Jurj, A.; Braicu, C.; Pop, L.-A.; Tomuleasa, C.; Gherman, C.D.; Berindan-Neagoe, I. The new era of nanotechnology, an alternative to change cancer treatment. Drug Des. Dev. Ther. 2017, 11, 2871-2890. [CrossRef] [PubMed]

163. Tomuleasa, C.; Braicu, C.; Irimie, A.; Craciun, L.; Berindan-Neagoe, I. Nanopharmacology in translational hematology and oncology. Int. J. Nanomed. 2014, 9, 3465-3479. [CrossRef]

164. Wu, S.; Lu, H.; Bai, Y. Nrf2 in cancers: A double-edged sword. Cancer Med. 2019. [CrossRef] [PubMed]

165. Tang, Z.; Li, C.; Kang, B.; Gao, G.; Li, C.; Zhang, Z. GEPIA: A web server for cancer and normal gene expression profiling and interactive analyses. Nucleic Acids Res. 2017, 45, W98-W102. [CrossRef]

166. Szklarczyk, D.; Gable, A.L.; Lyon, D.; Junge, A.; Wyder, S.; Huerta-Cepas, J.; Simonovic, M.; Doncheva, N.T.; Morris, J.H.; Bork, P.; et al. STRING v11: Protein-protein association networks with increased coverage, supporting functional discovery in genome-wide experimental datasets. Nucleic Acids Res. 2019, 47, D607-D613. [CrossRef]

(C) 2019 by the authors. Licensee MDPI, Basel, Switzerland. This article is an open access article distributed under the terms and conditions of the Creative Commons Attribution (CC BY) license (http://creativecommons.org/licenses/by/4.0/). 